\title{
Supporting Information for Methyl Scanning: Total Synthesis of Demethylasterriquinone B1 and Derivatives for Identification of Sites of Interaction with and Isolation of Its Receptor(s)
}

\footnotetext{
${ }^{1}$ Department of Chemistry, Levine Science Research Center, Box 90317, Duke University, Durham, North Carolina 27708-0317

${ }^{2}$ Department of Medicine, University of California-San Diego, 9500 Gilman Drive, La Jolla, California 92093, and the San Diego Veterans Healthcare System, CA 92161

*Current address: Department of Chemistry, University of California, Riverside, CA 92521-0403. michael.pirrung@ucr.edu
} 

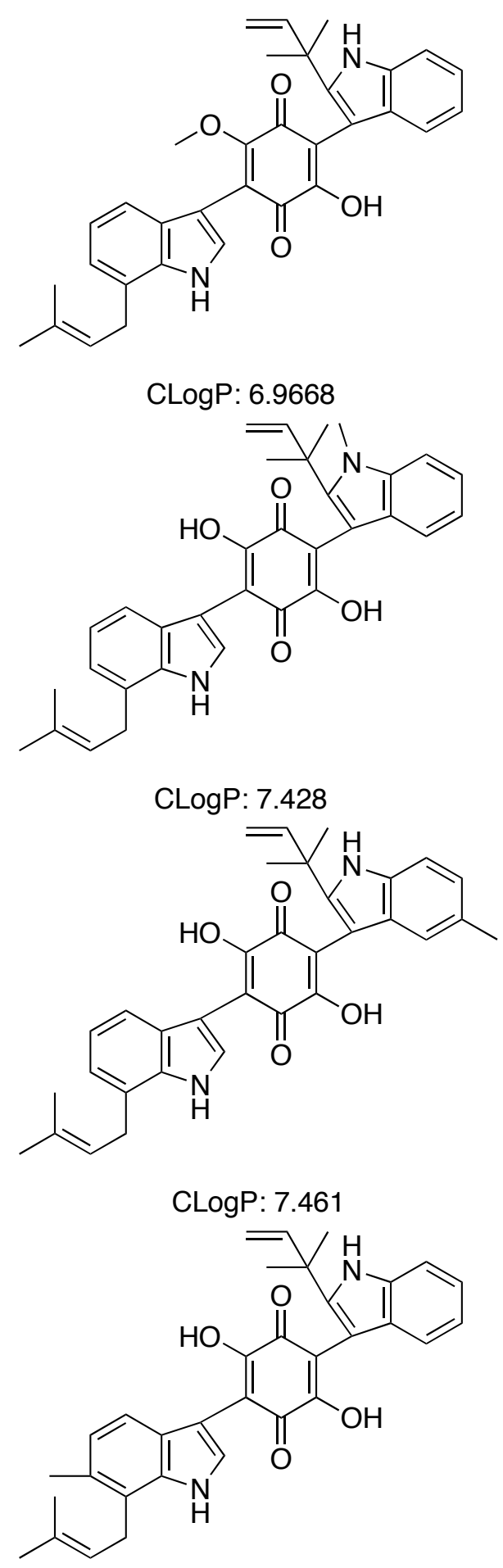

CLogP: 7.411
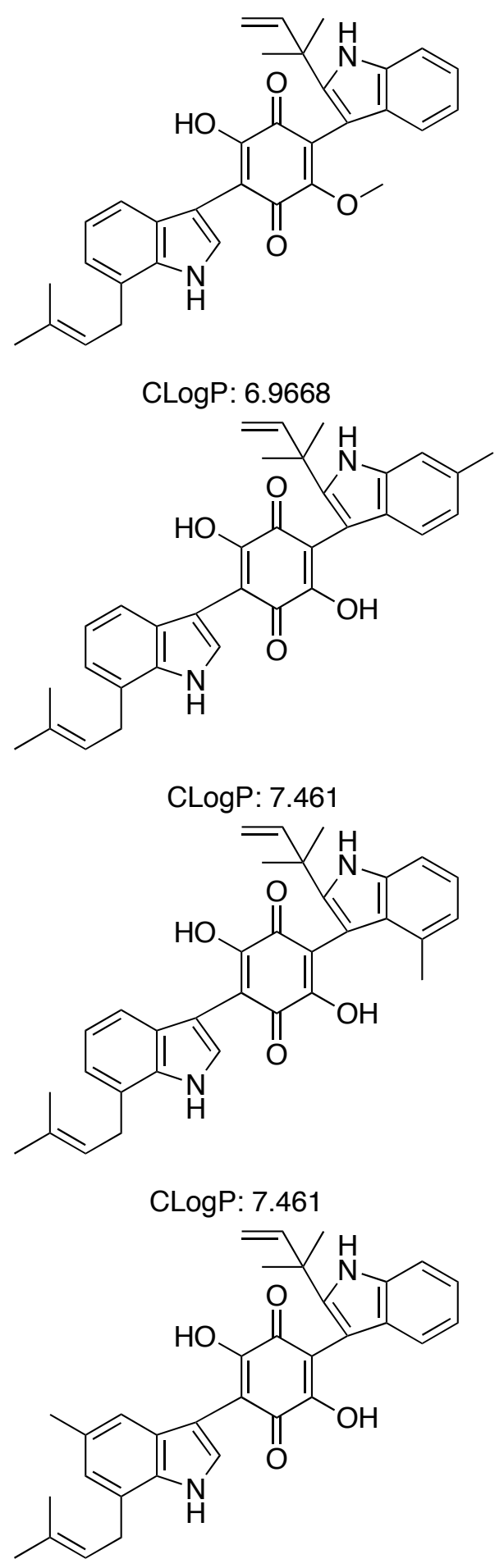

$$
\text { CLogP: } 7.461
$$

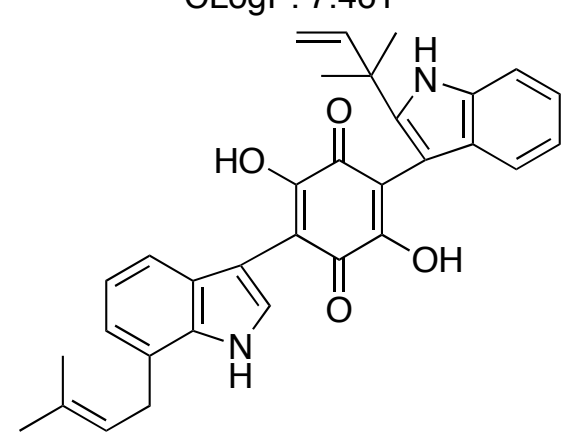

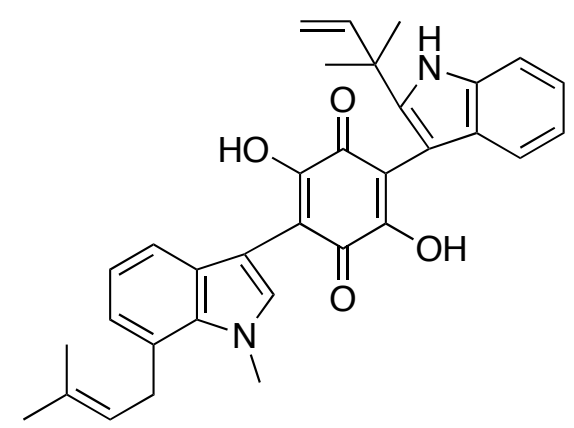

CLogP: 7.428
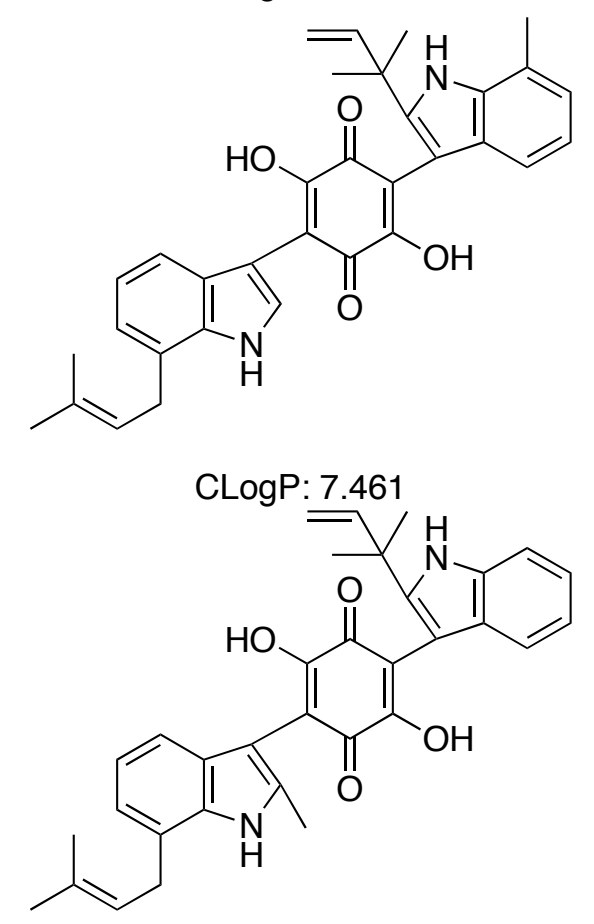

CLogP: 7.461

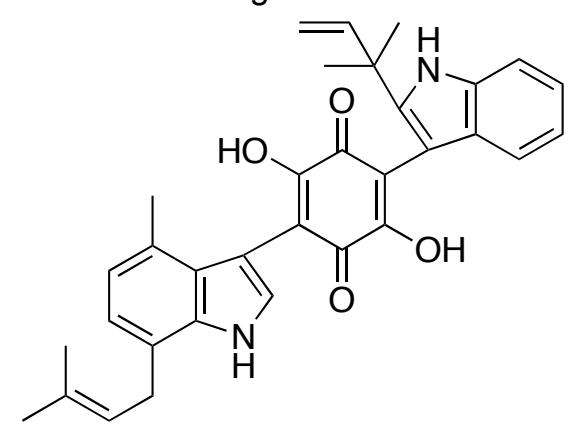

CLogP: 7.461 


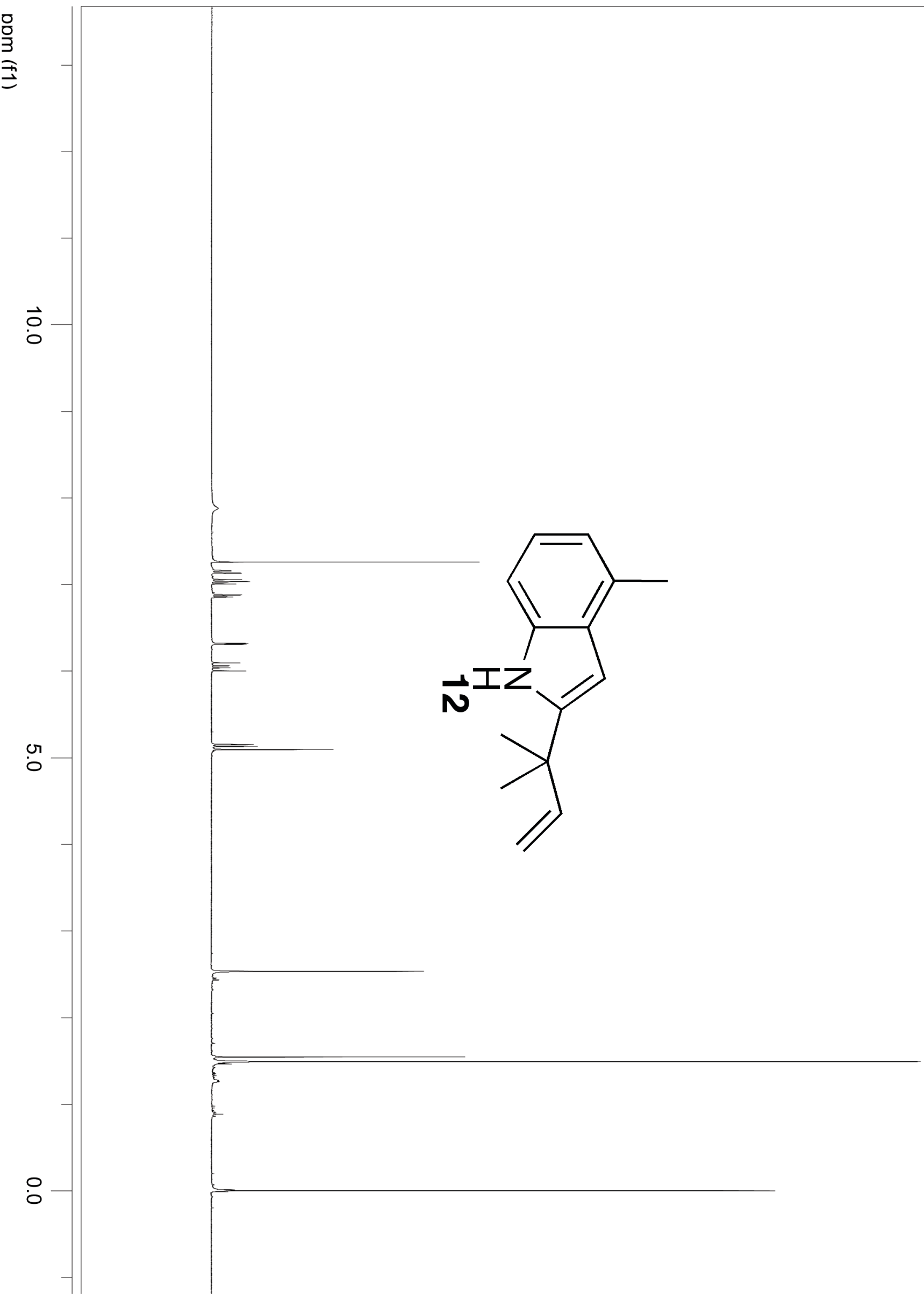




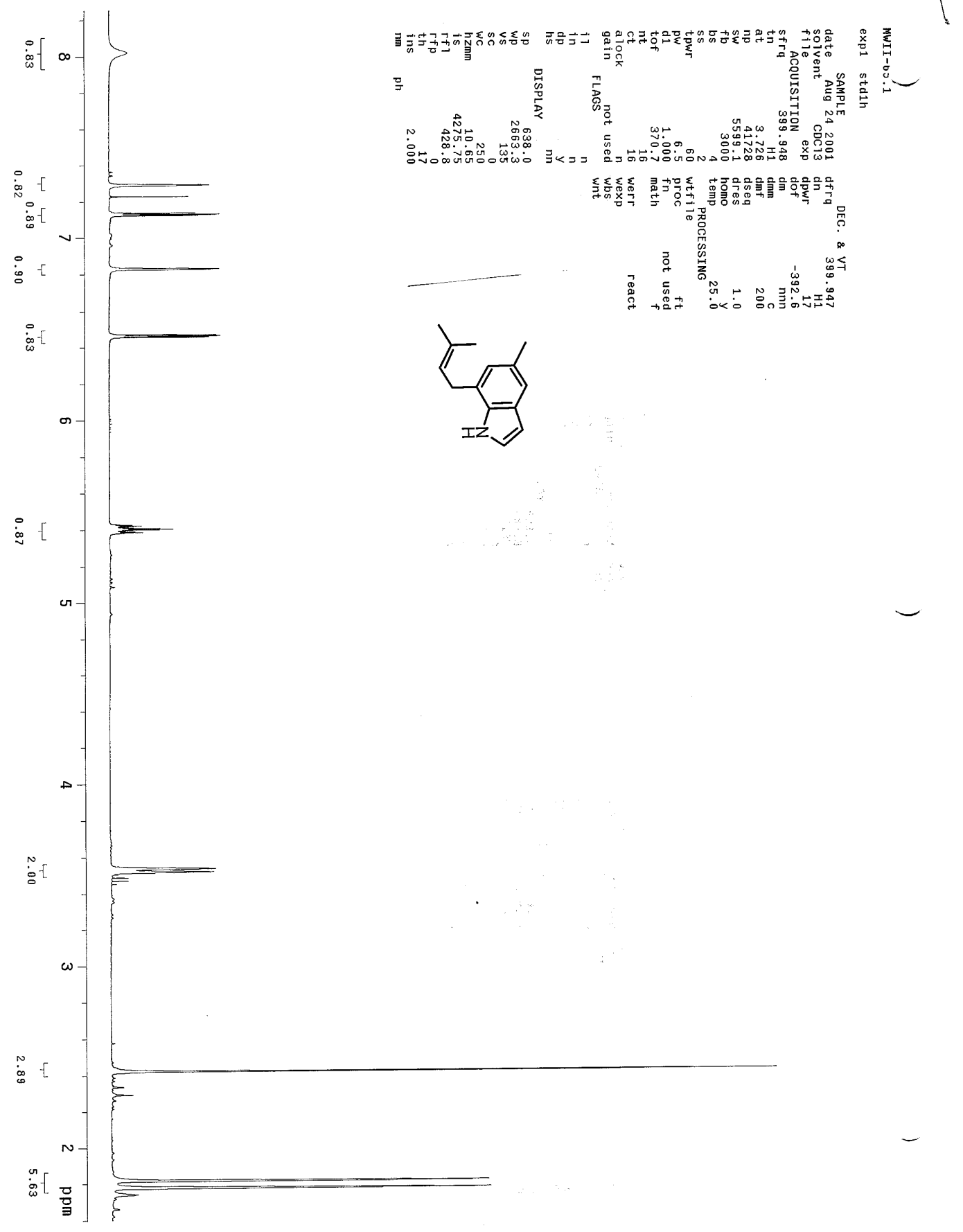




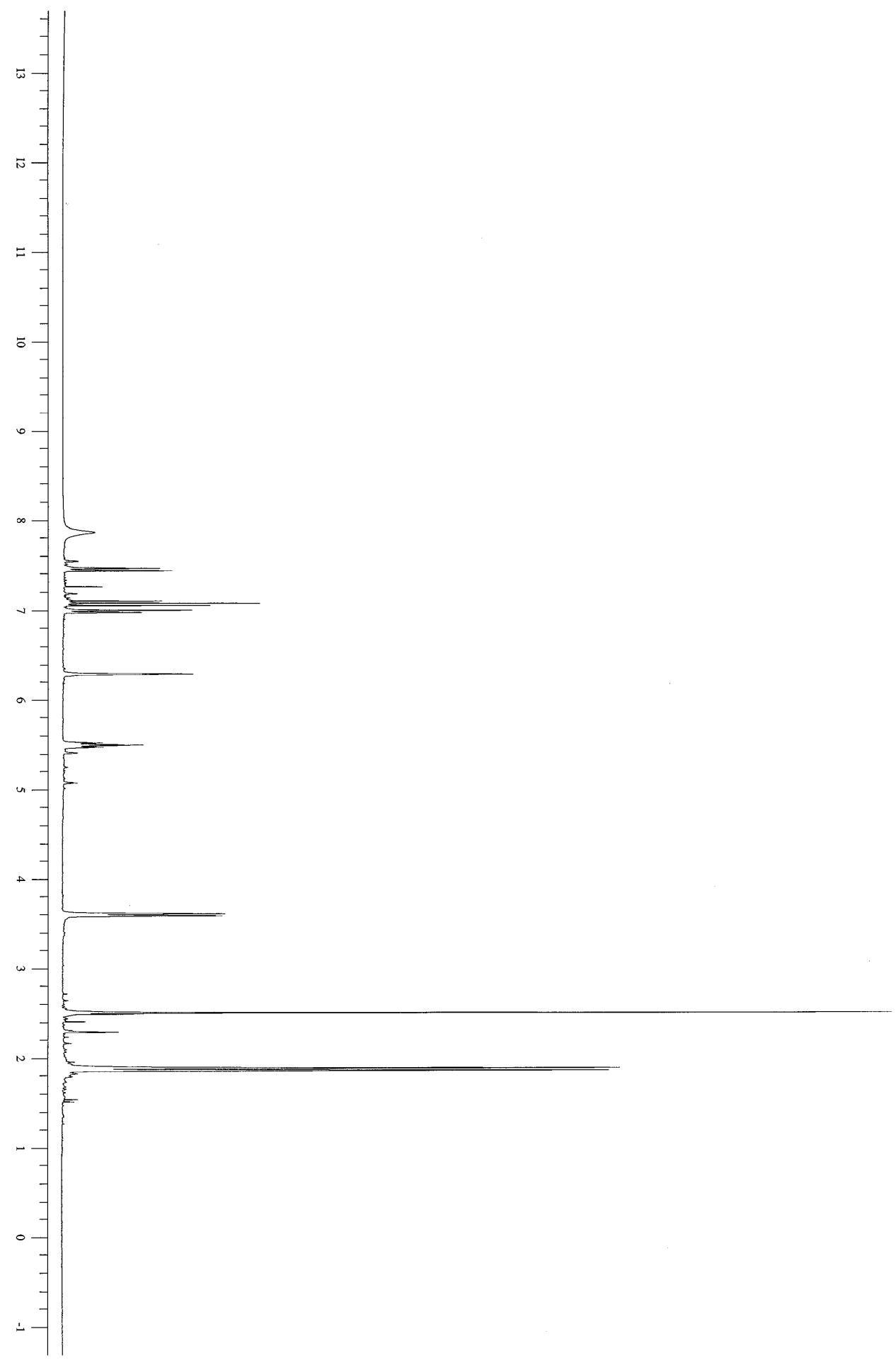




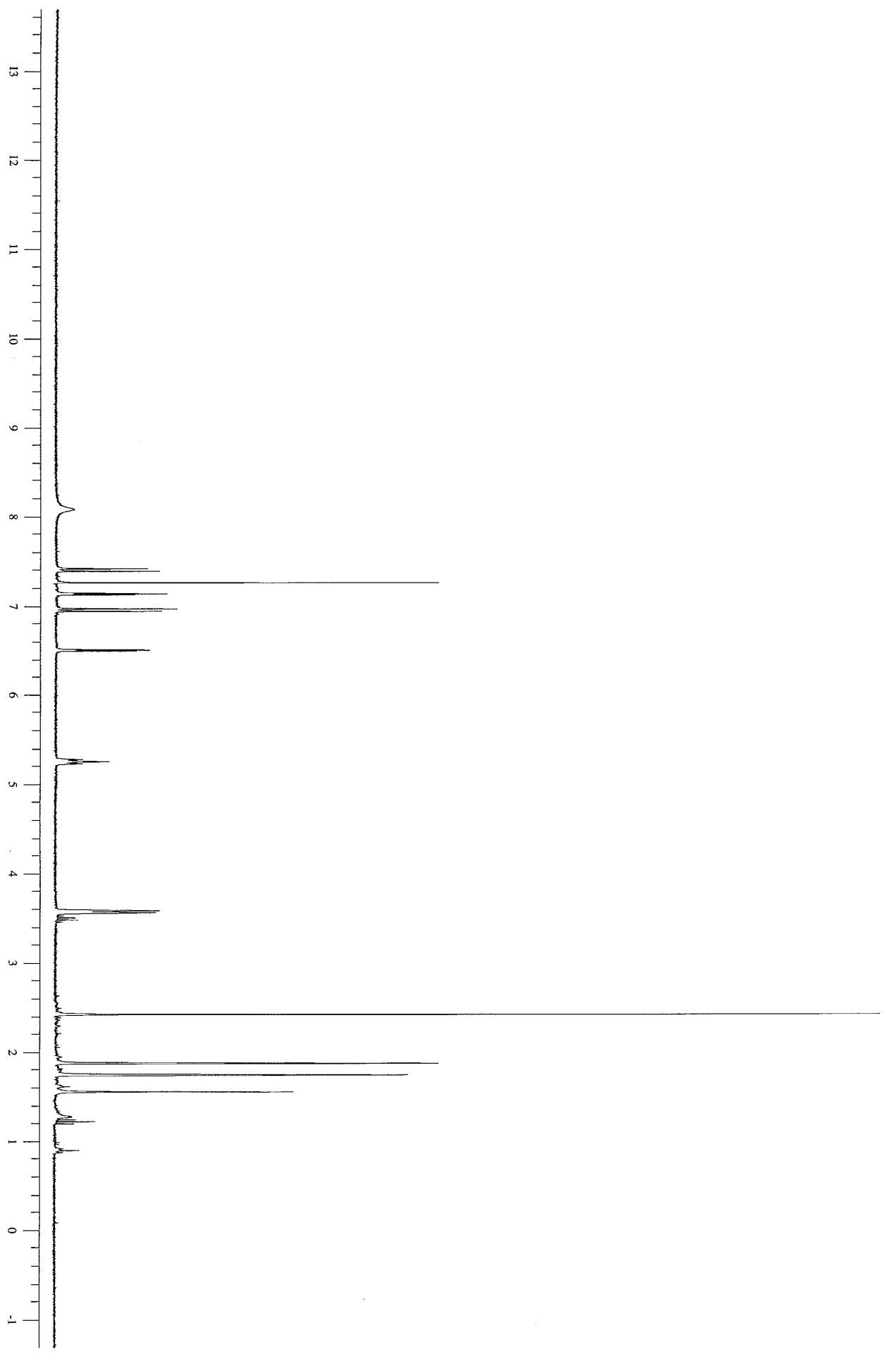




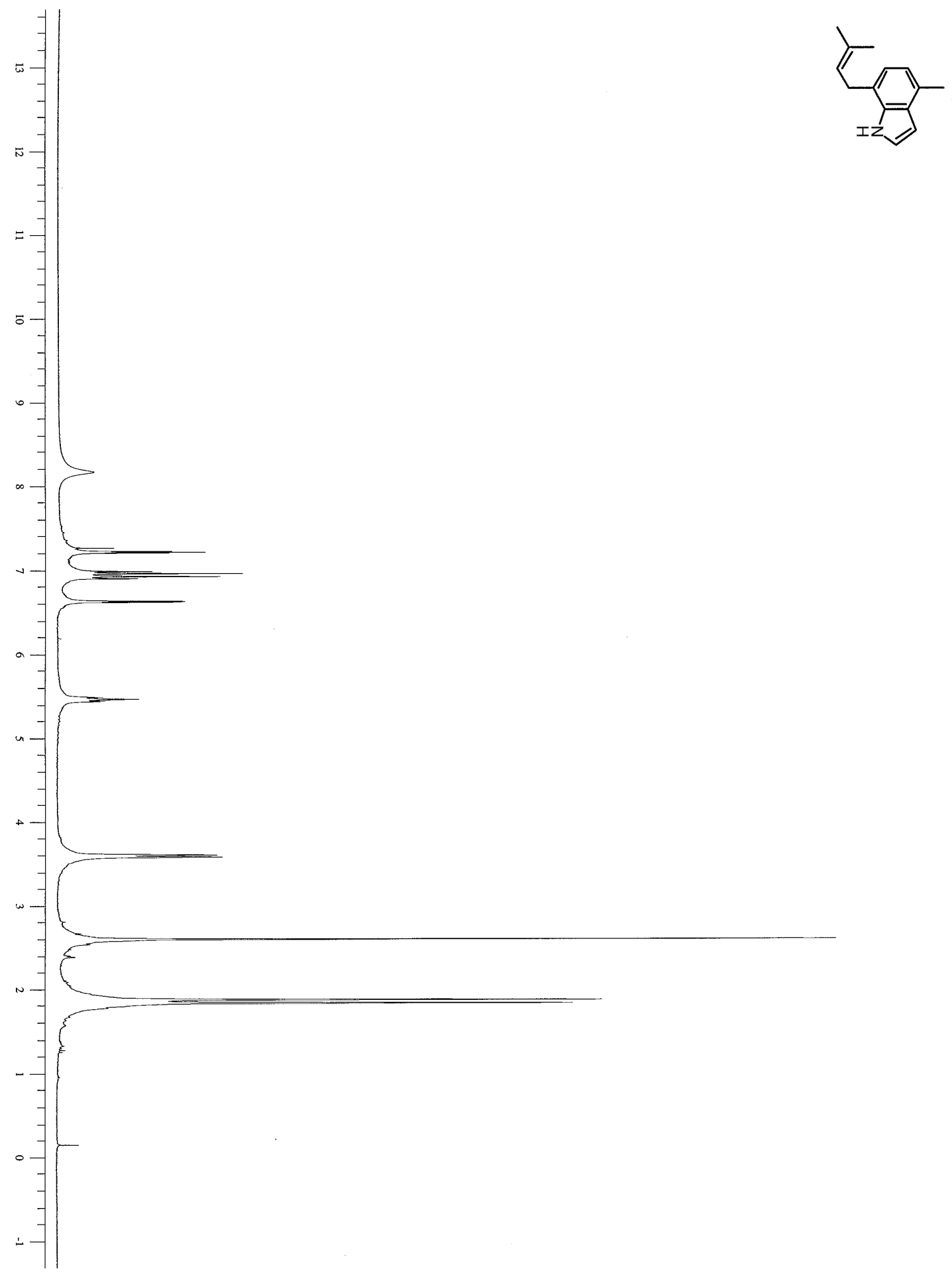




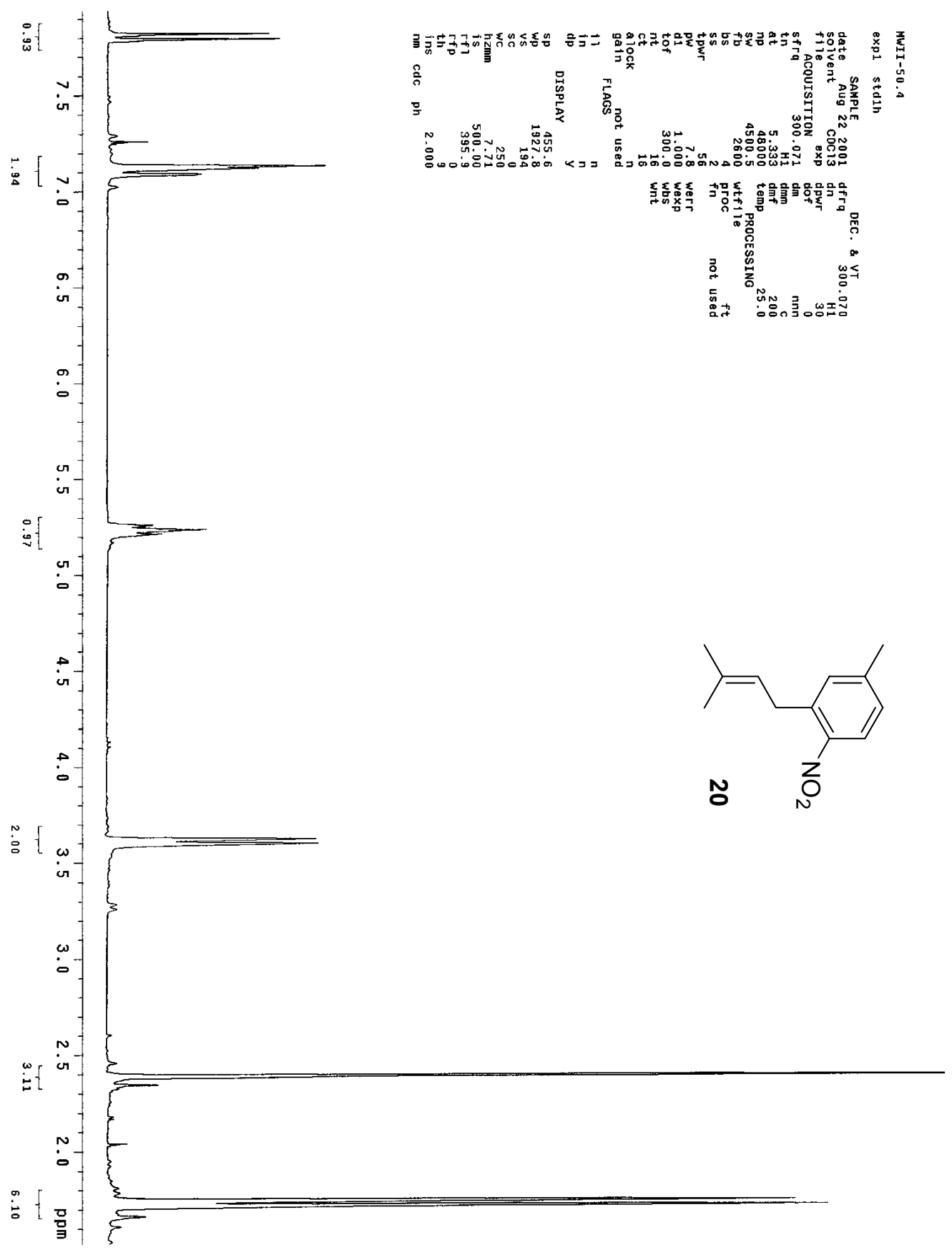




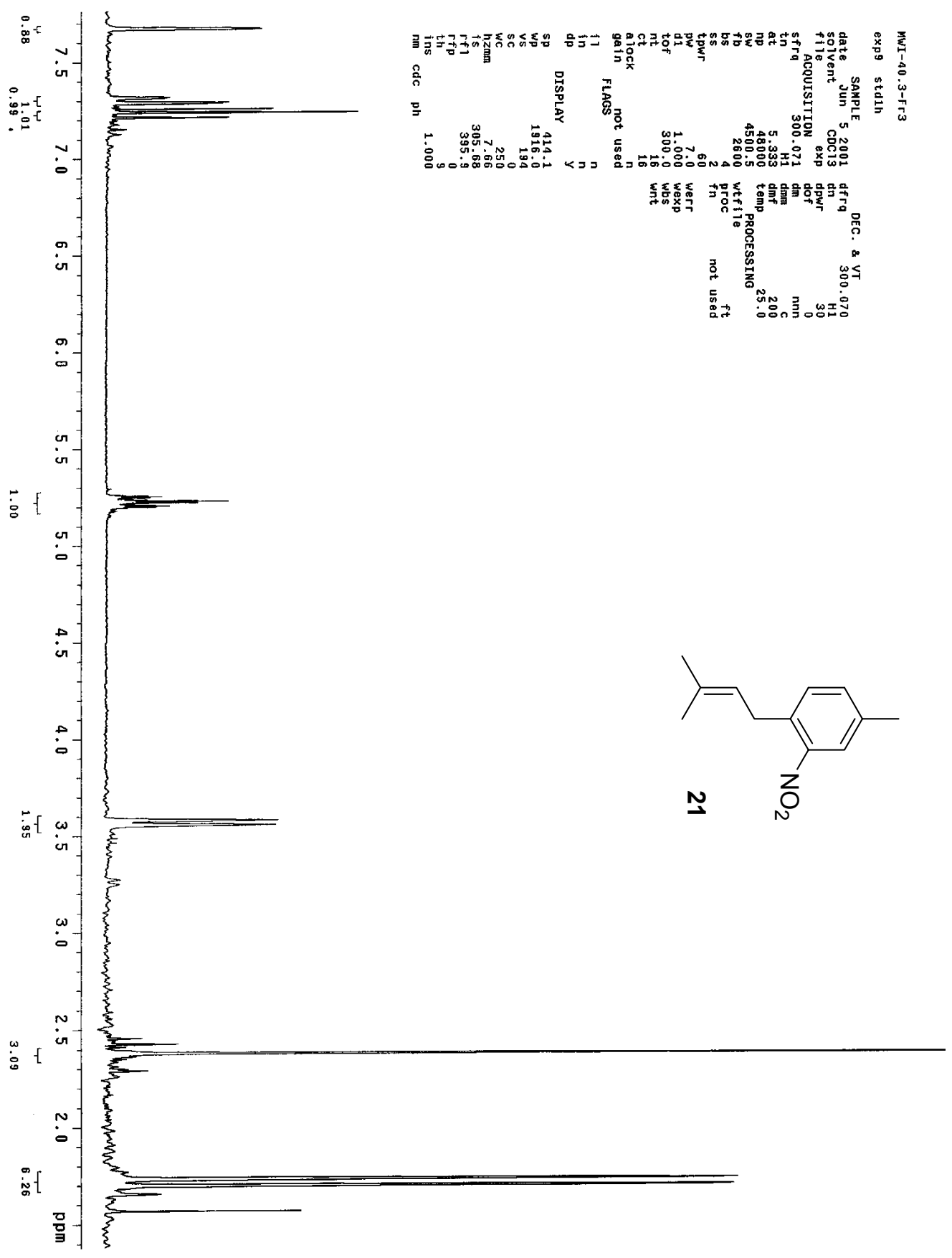




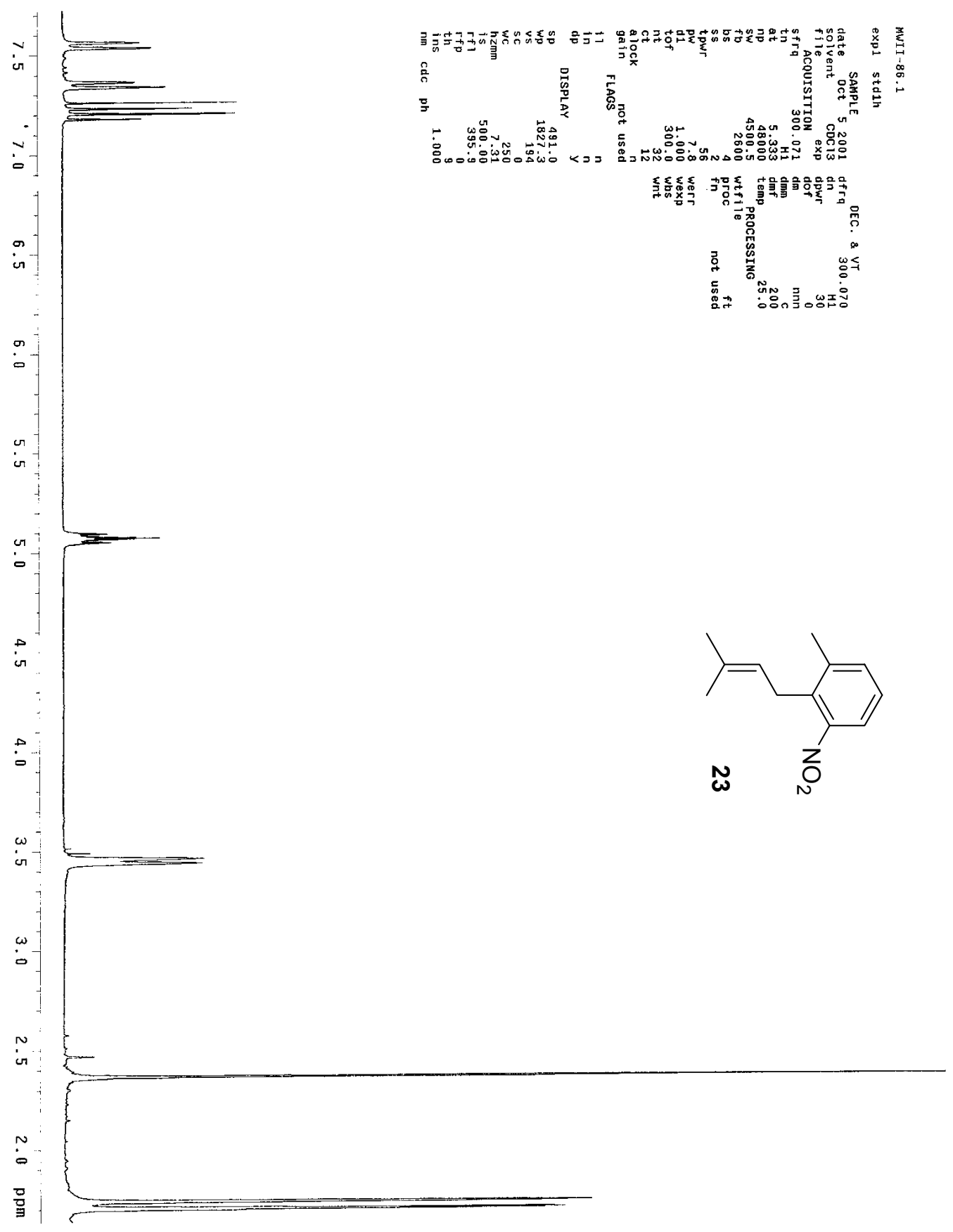




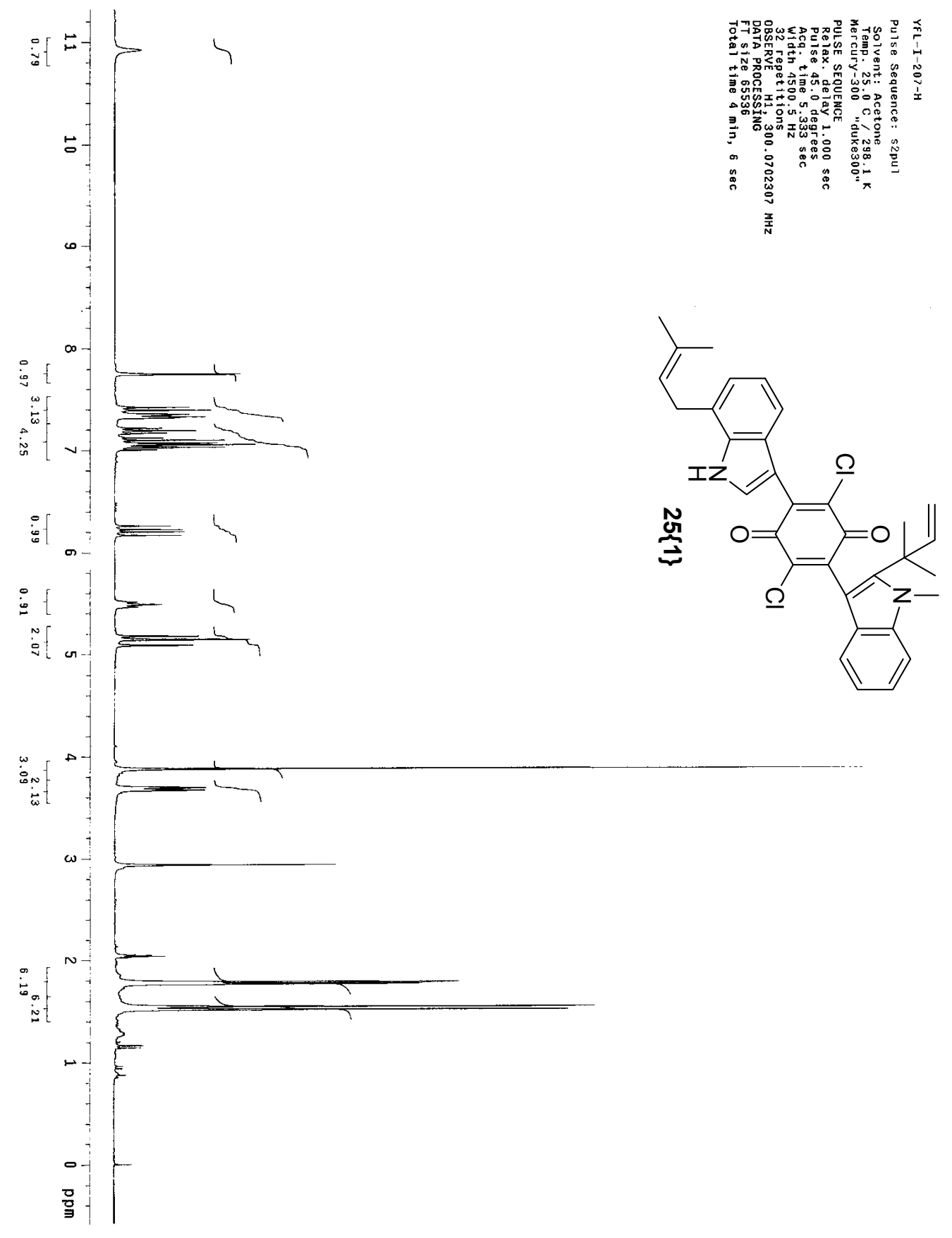




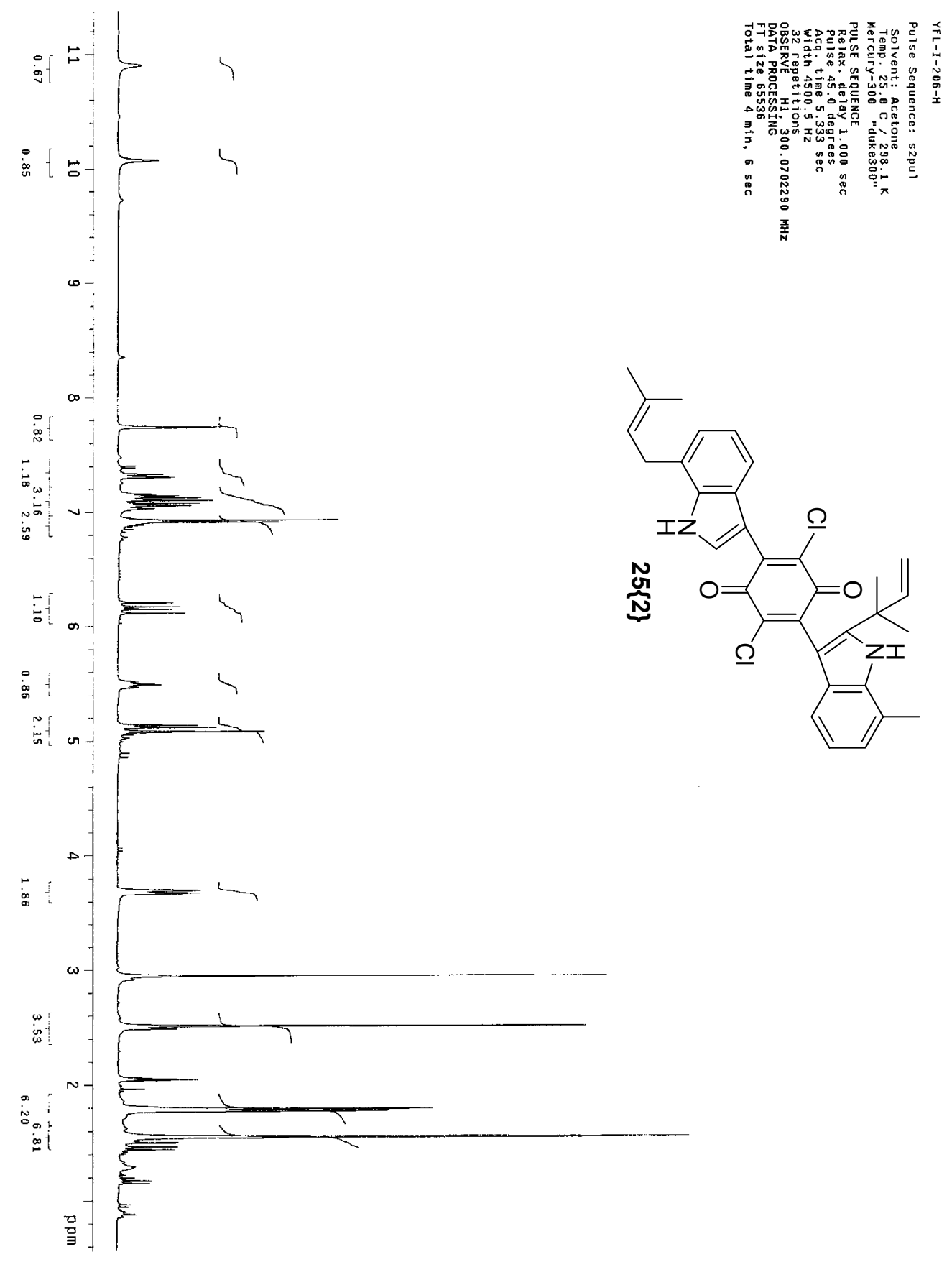




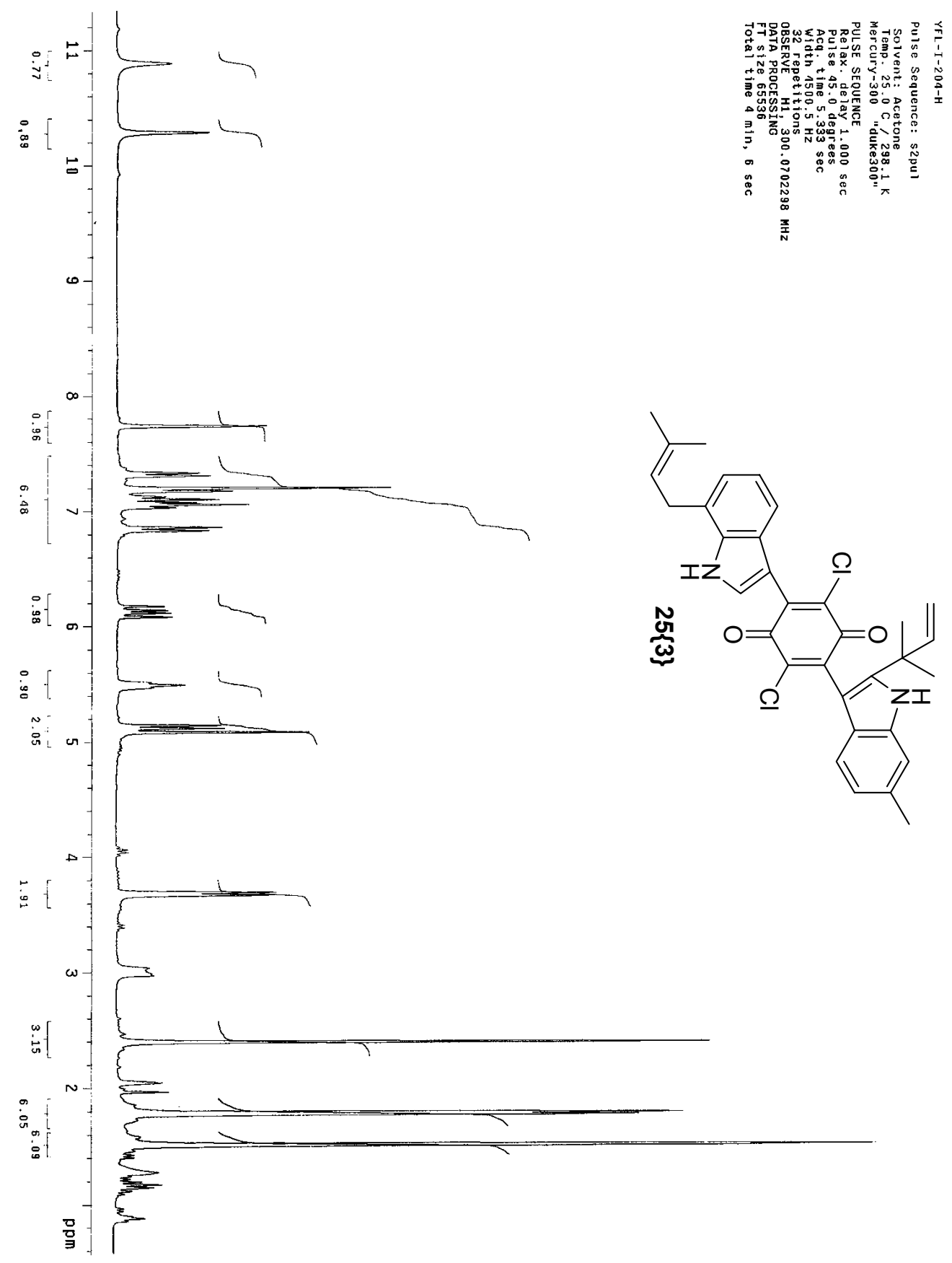




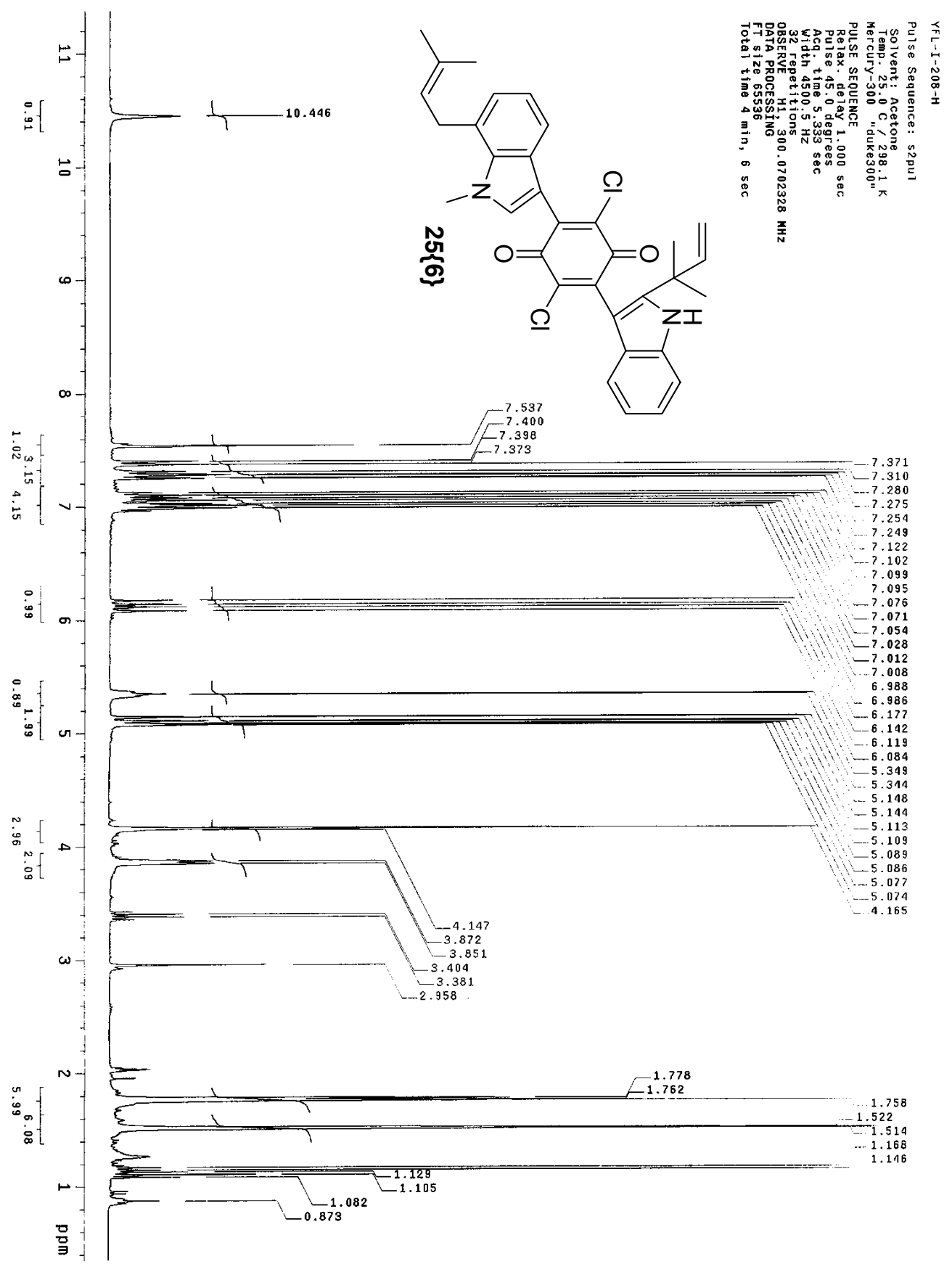




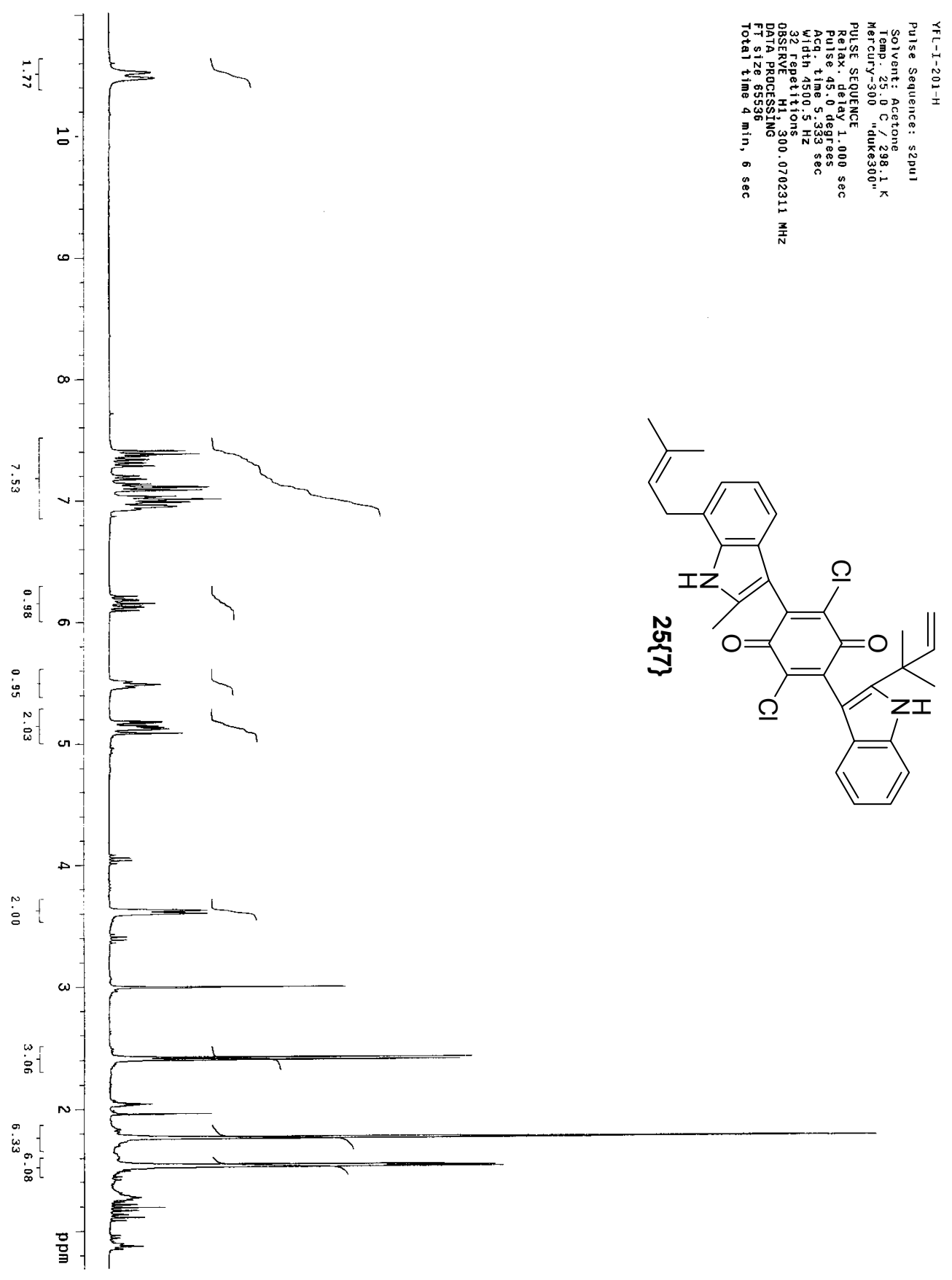




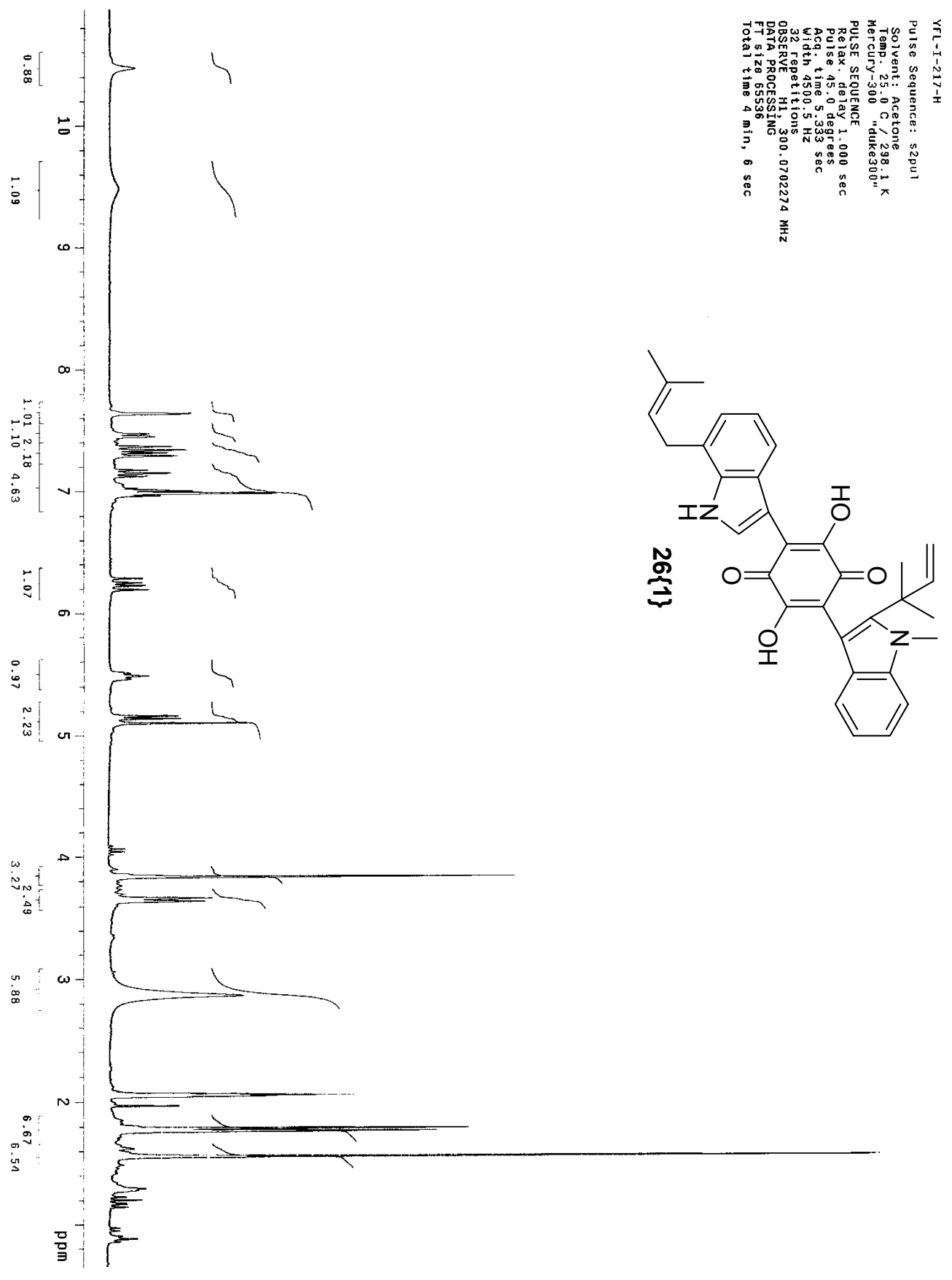




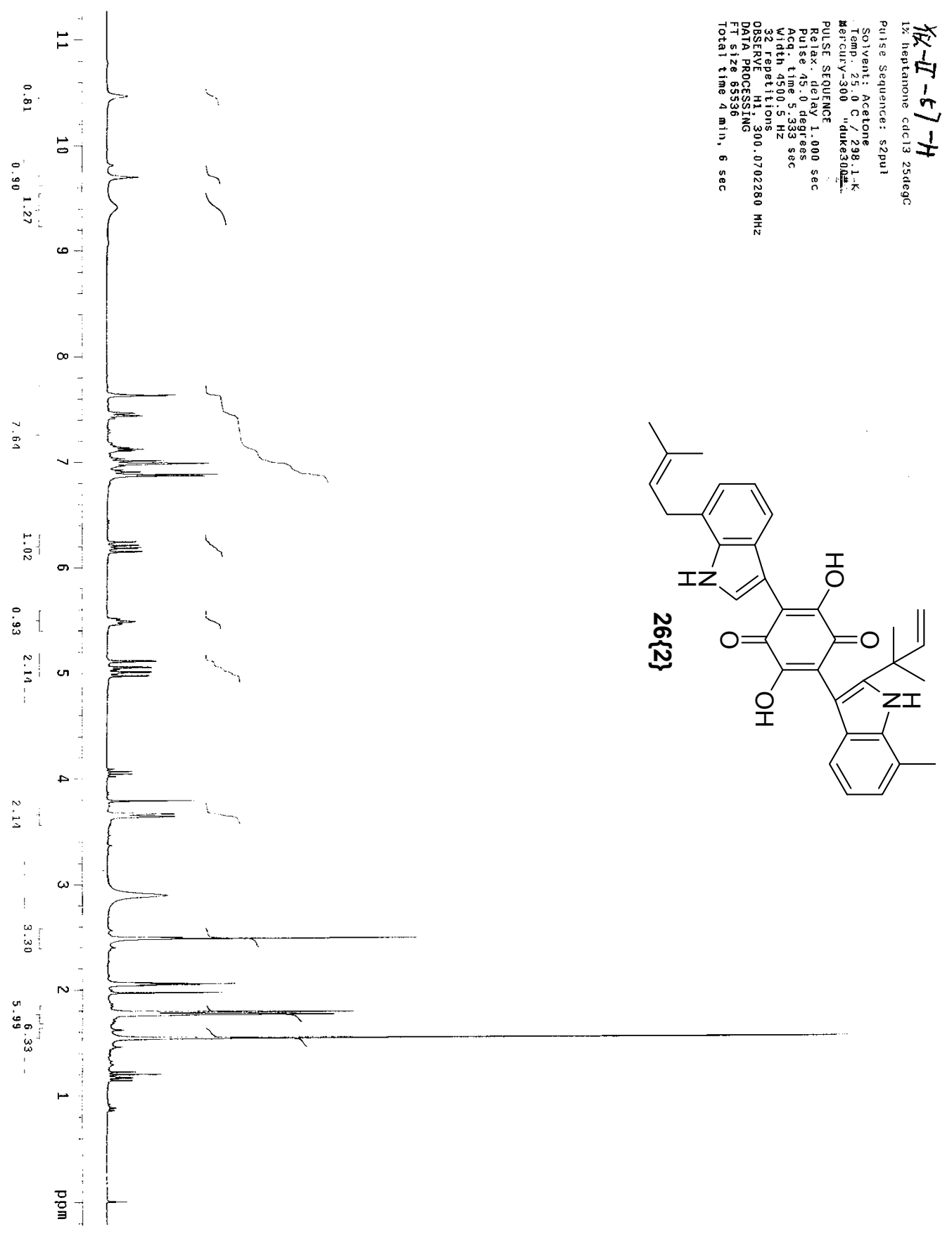




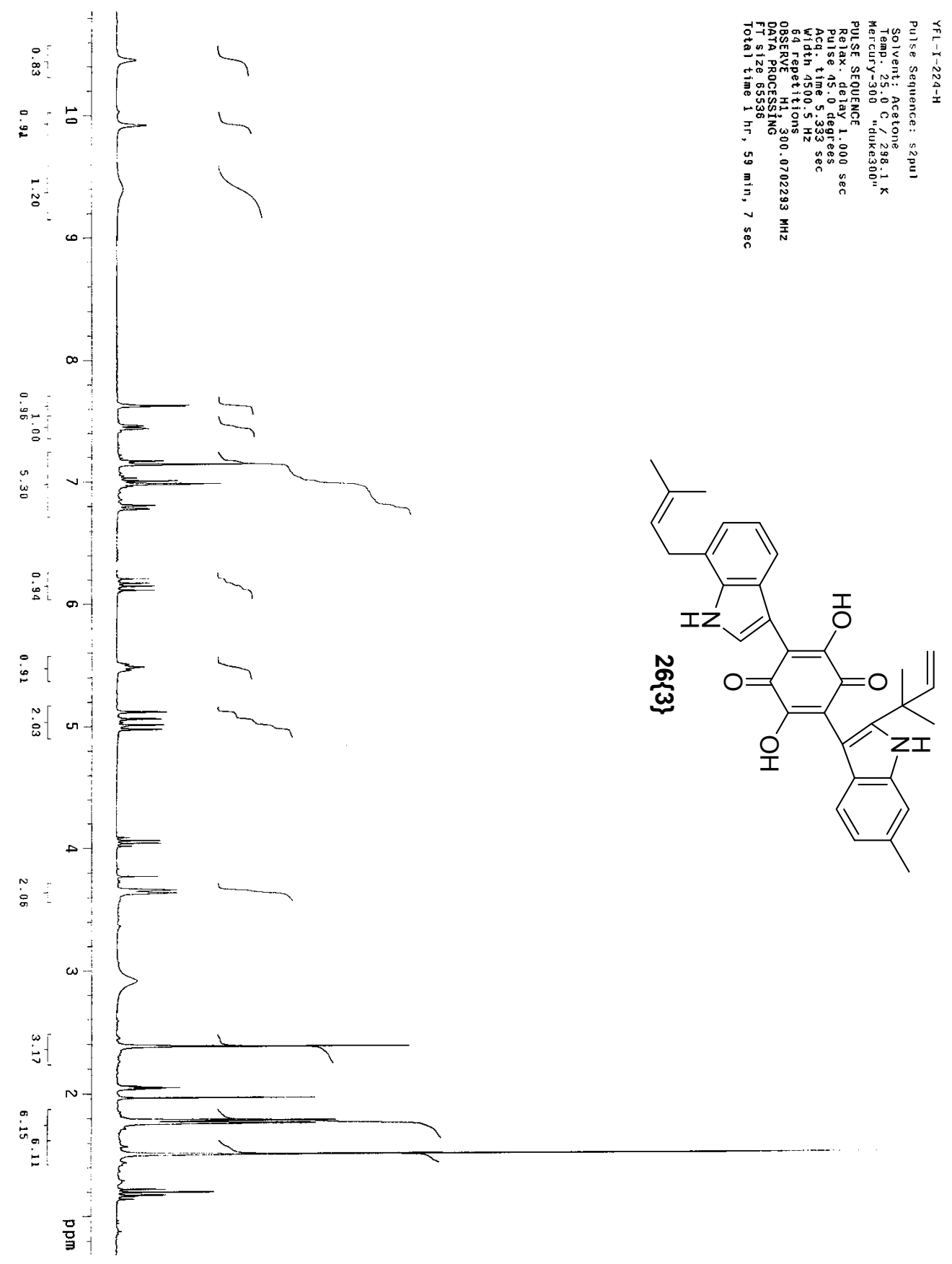




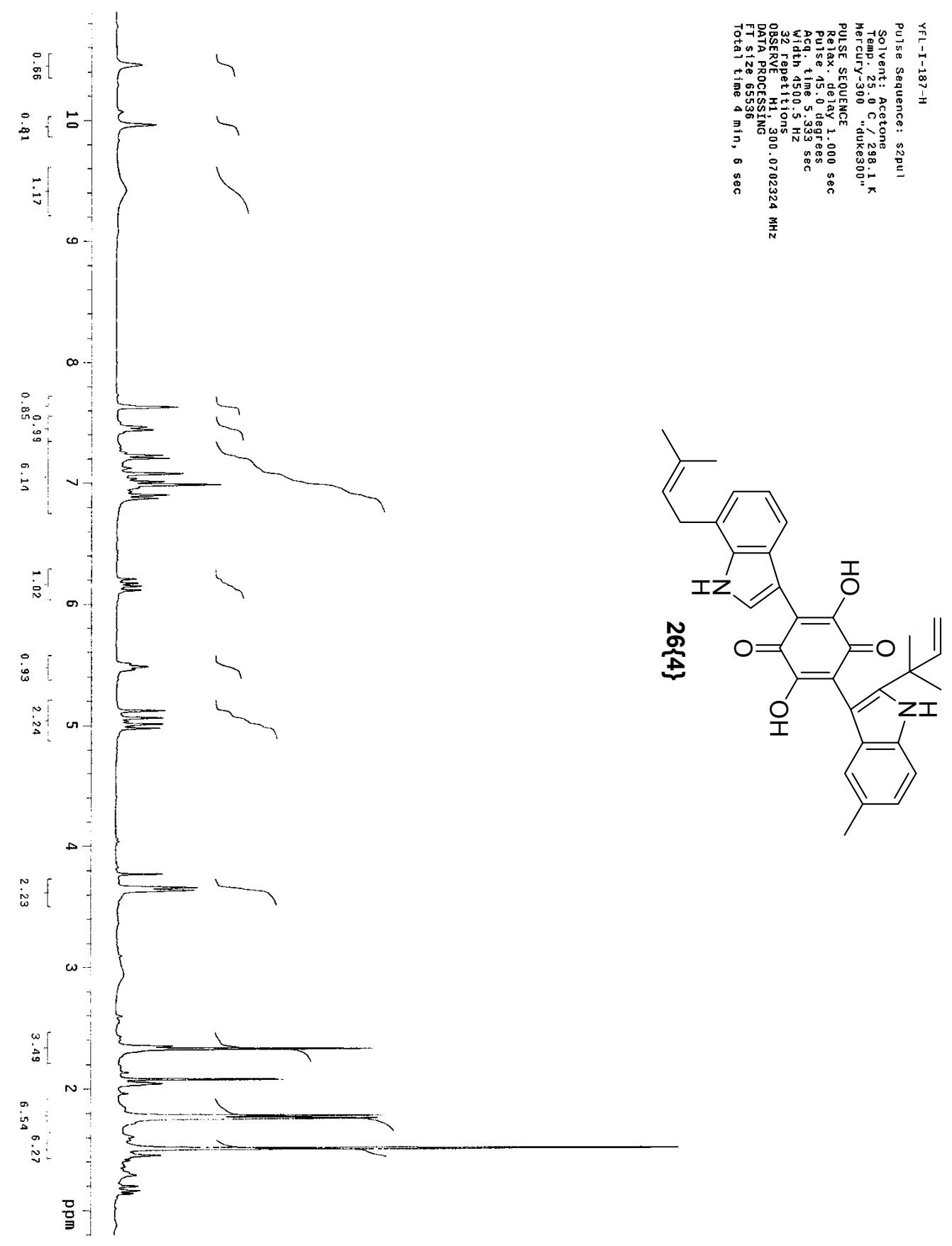




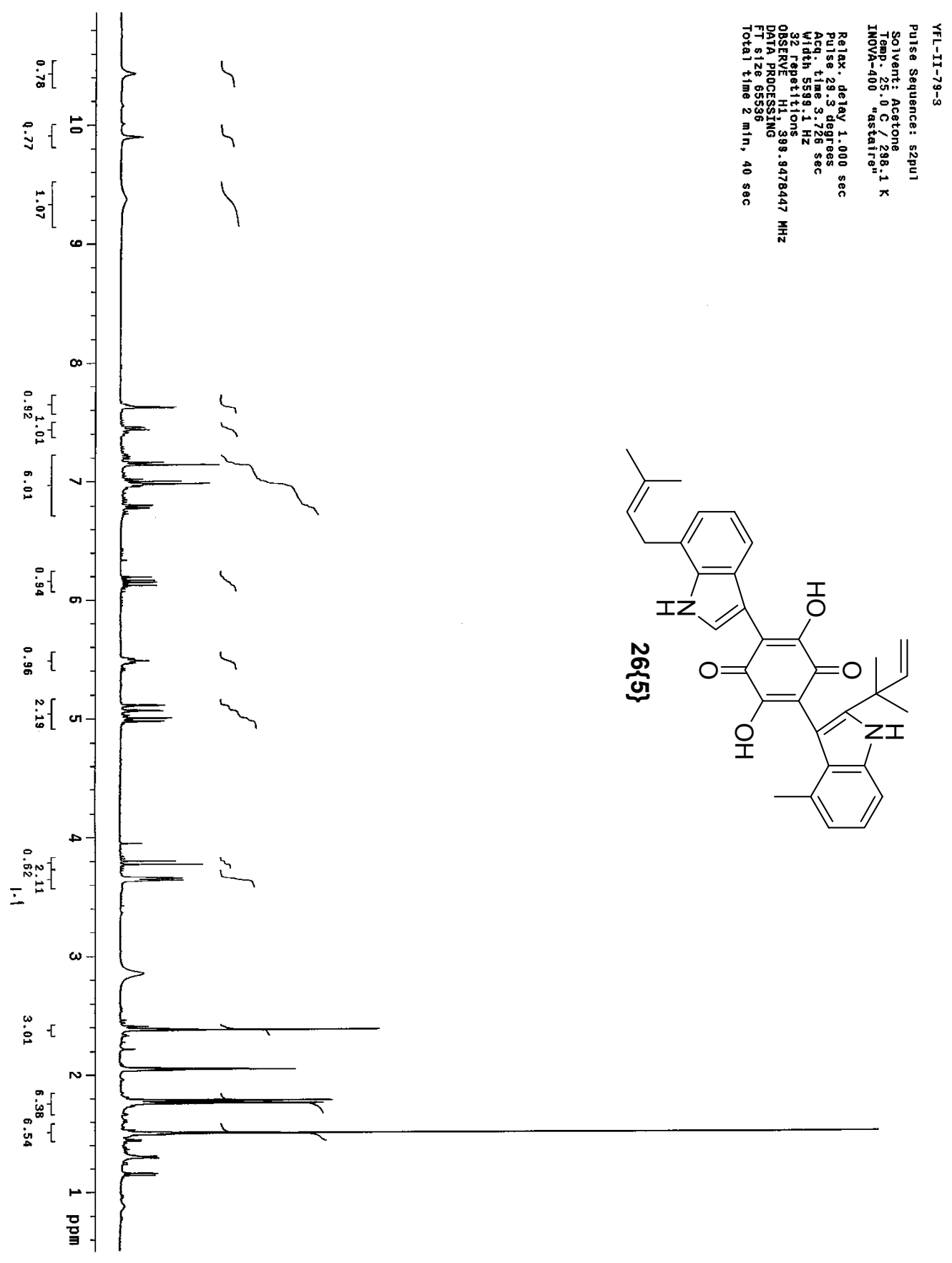




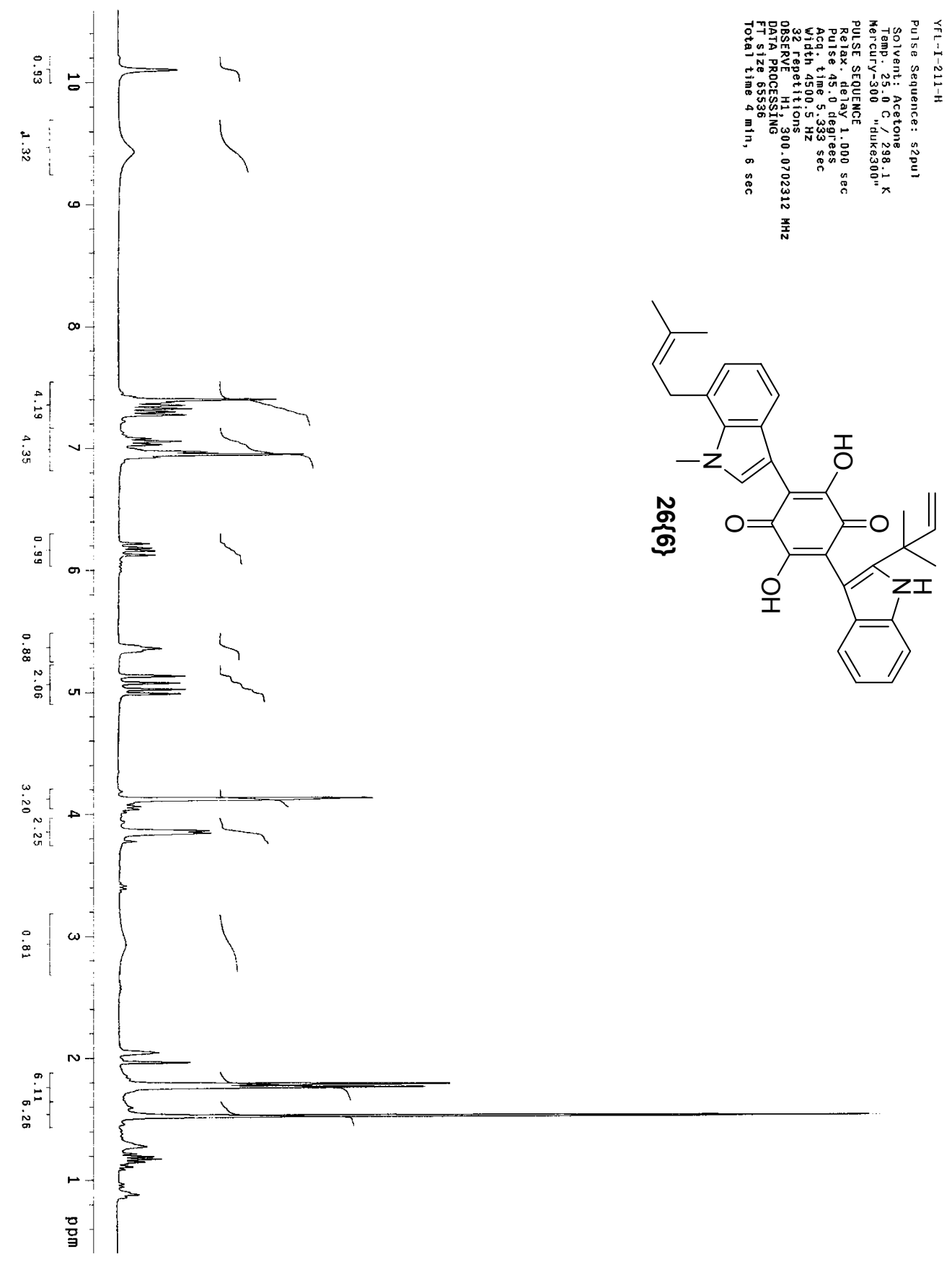




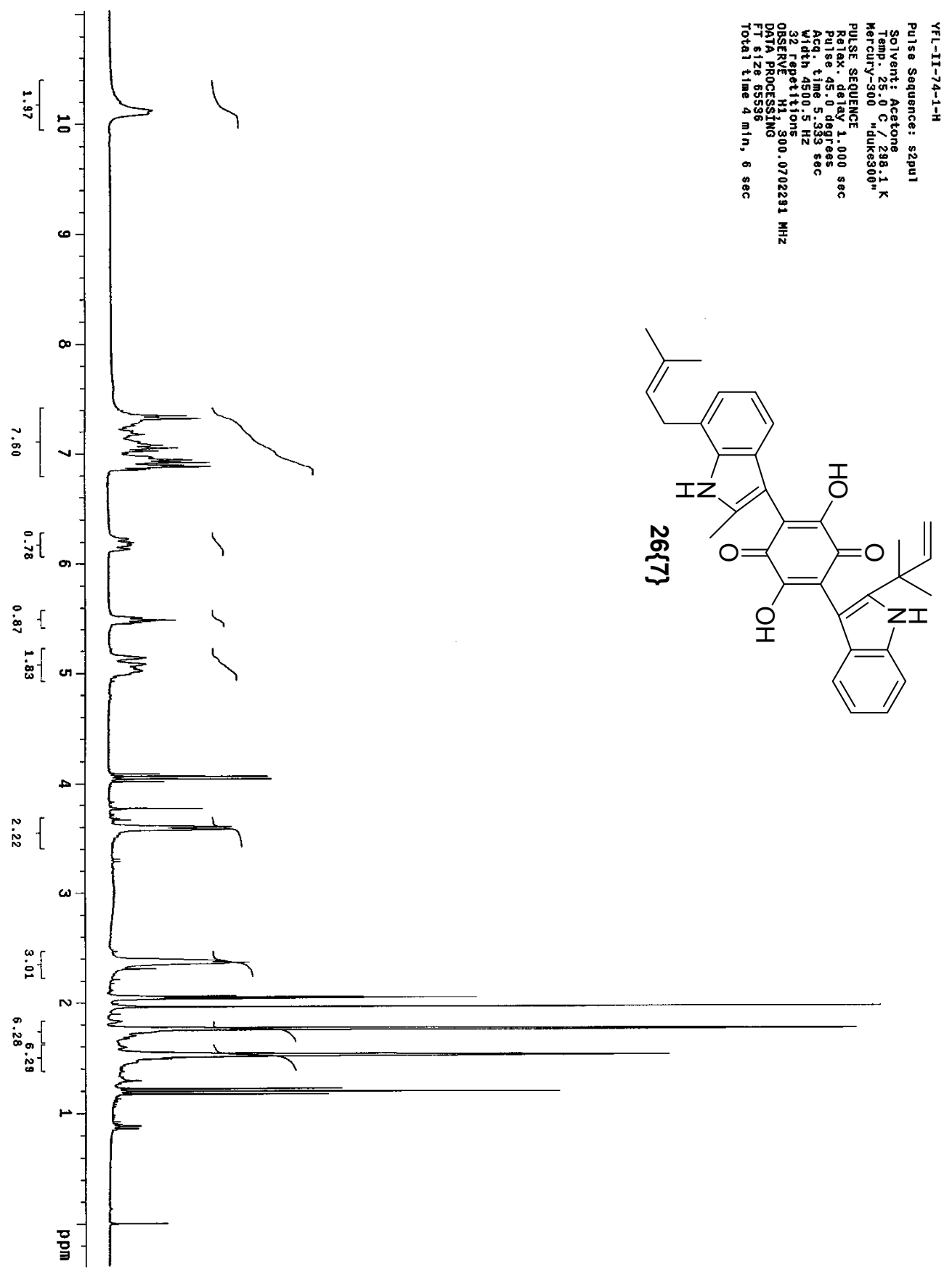




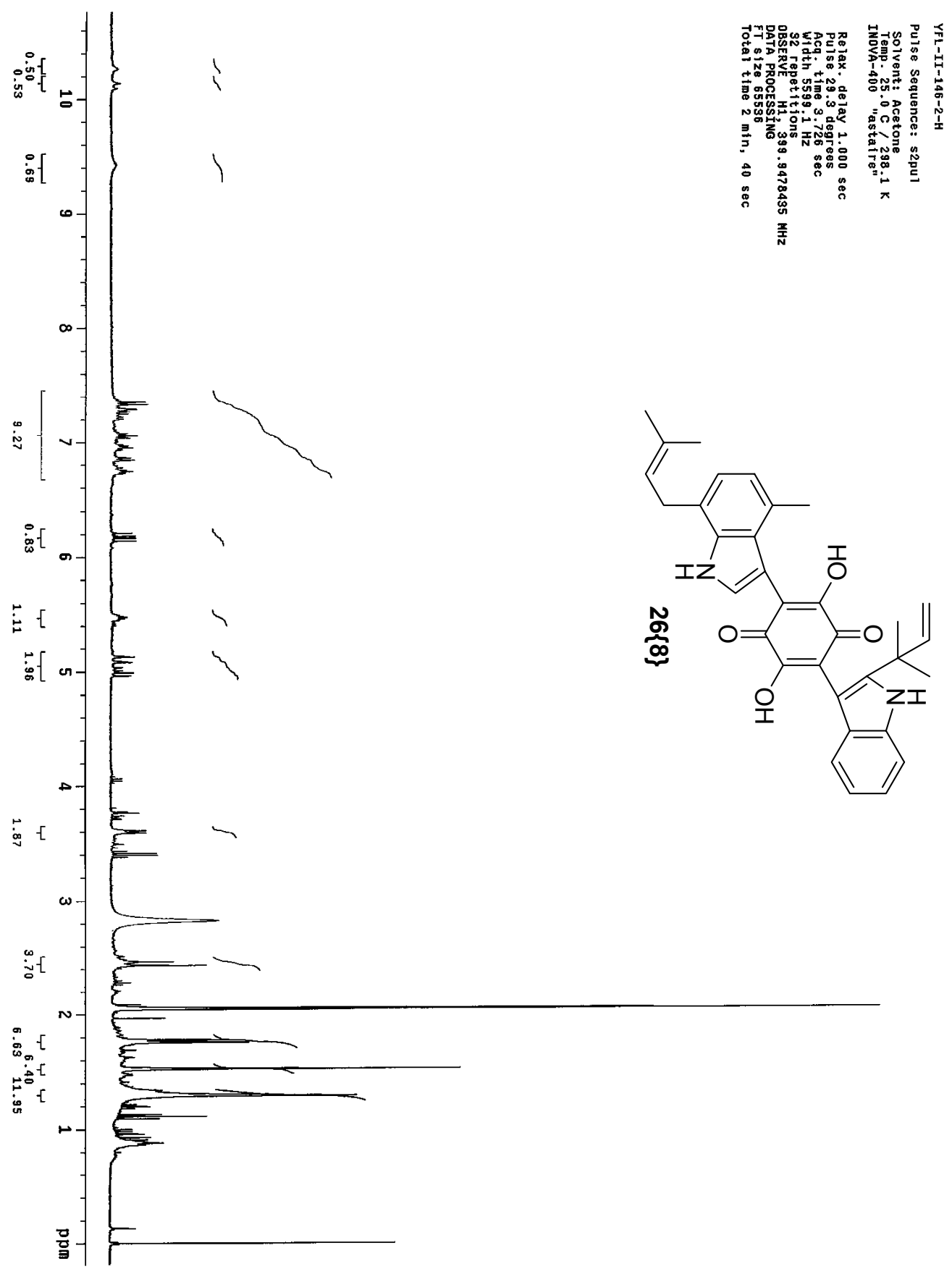




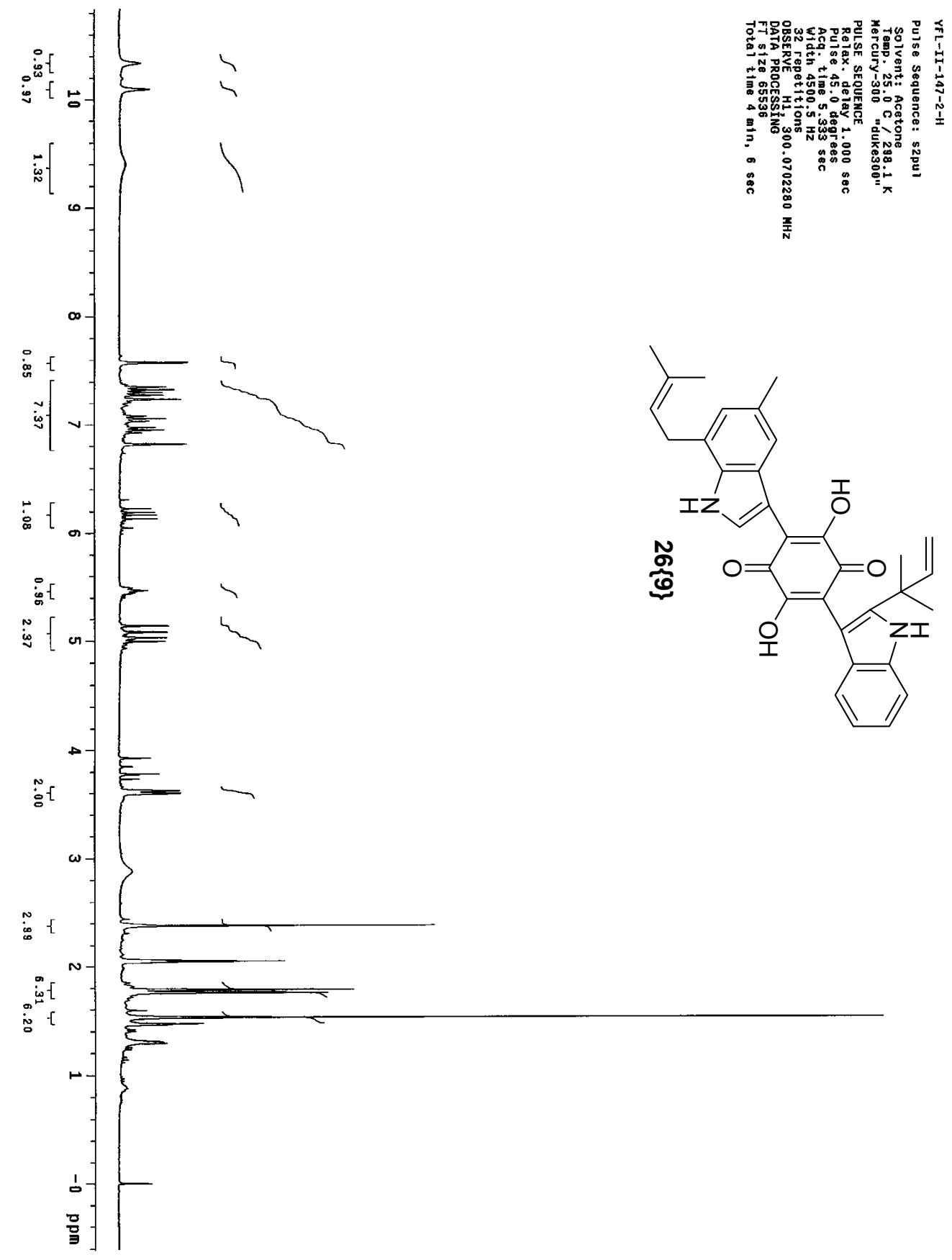




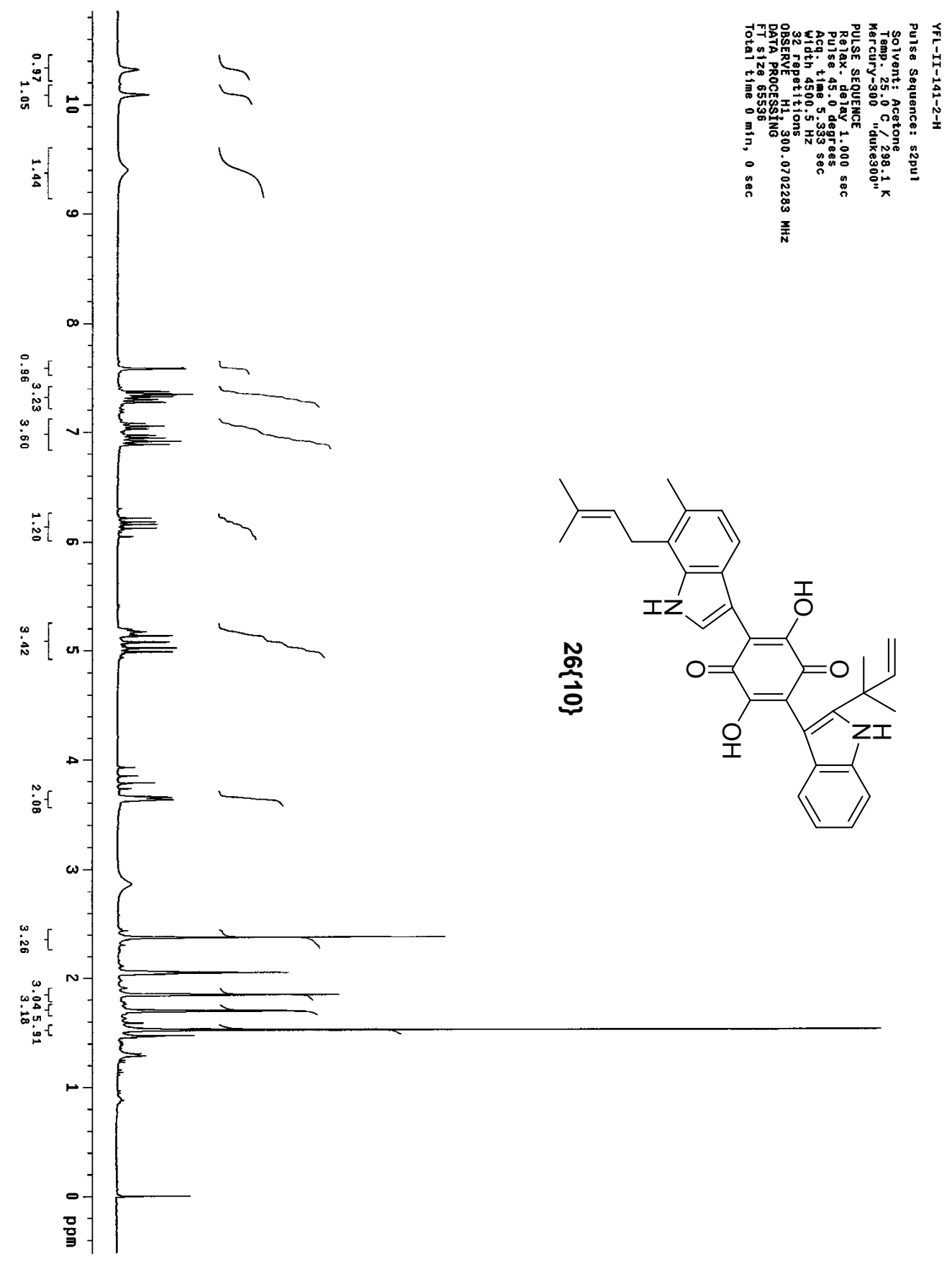




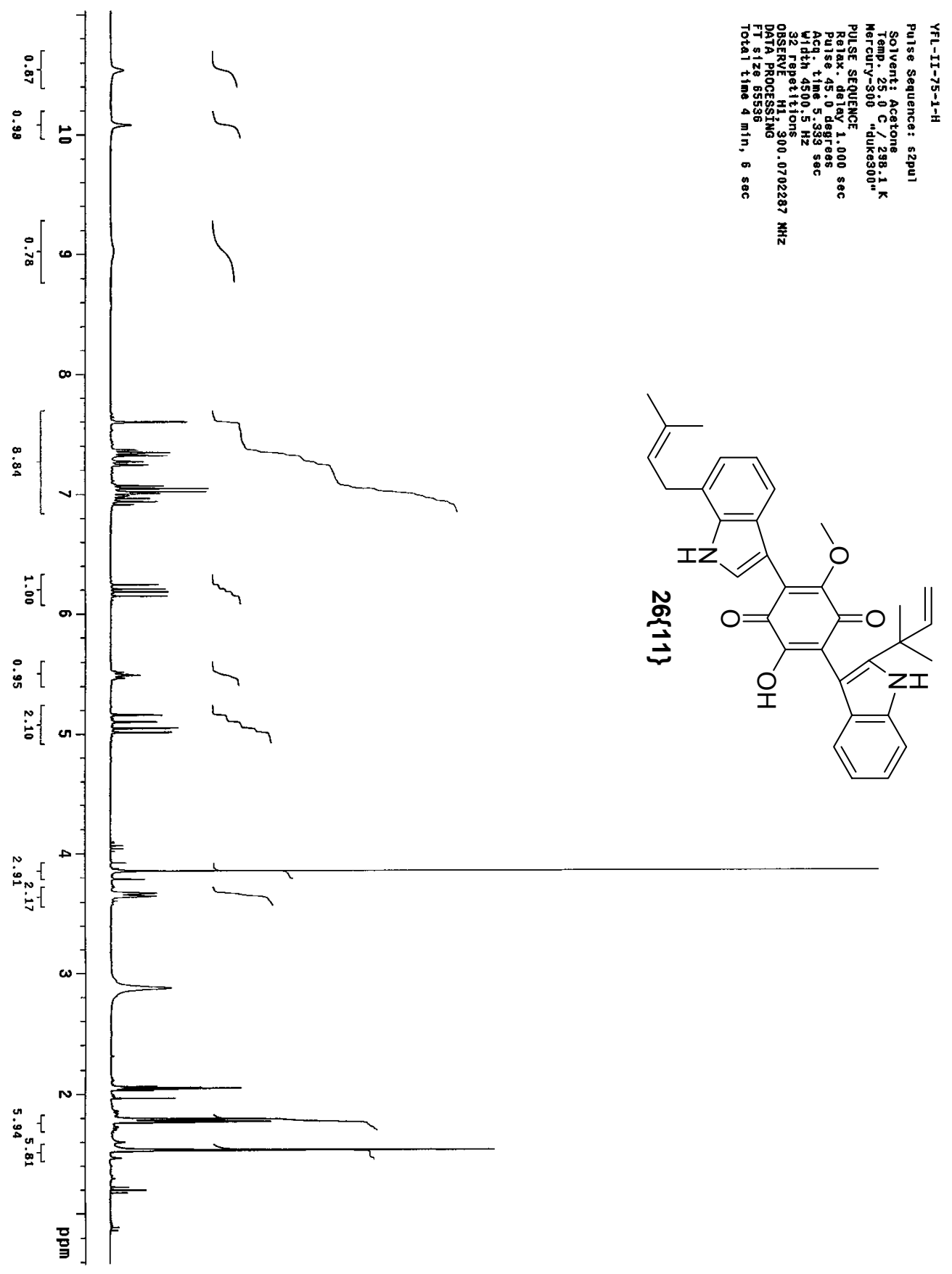




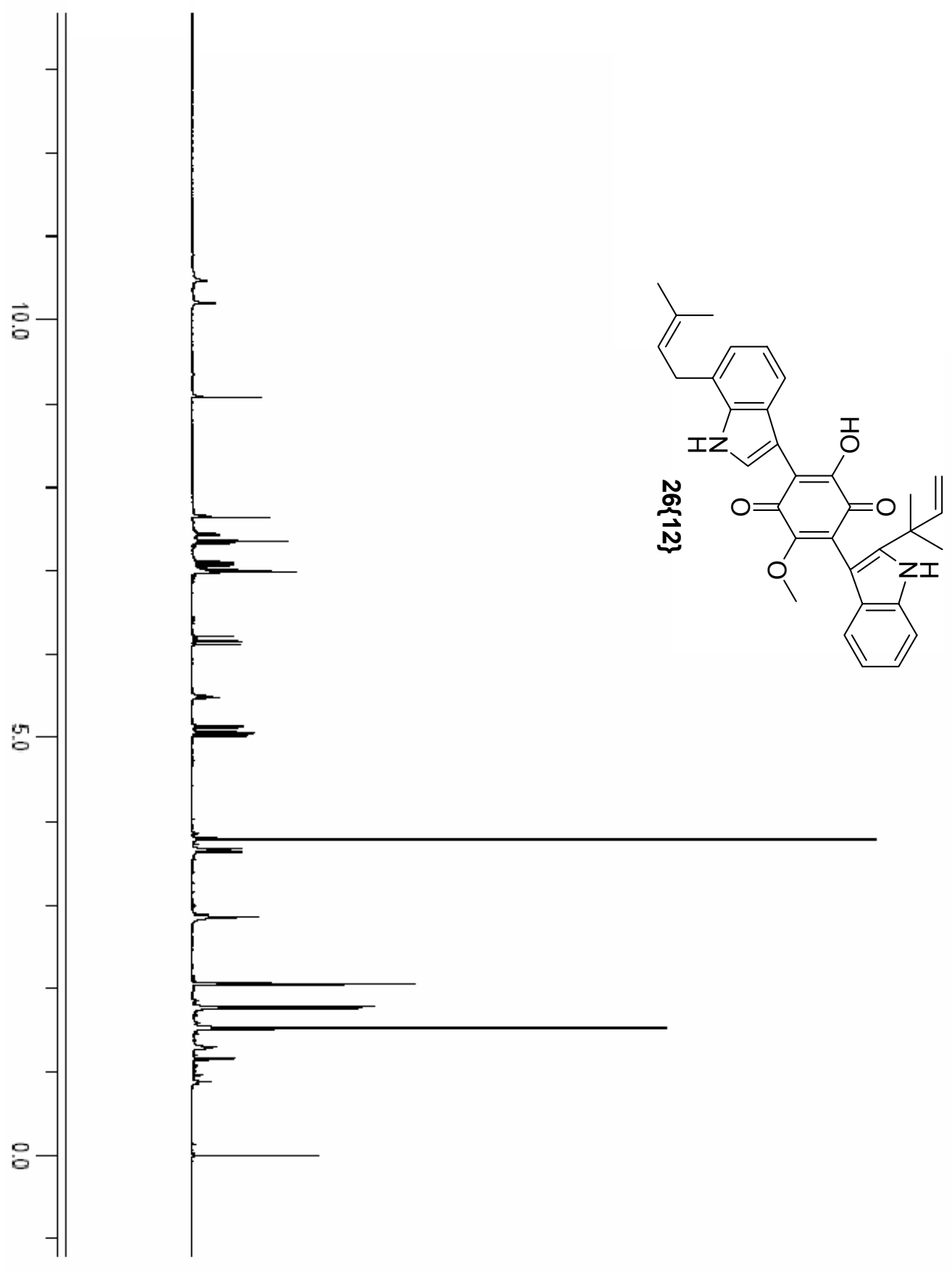




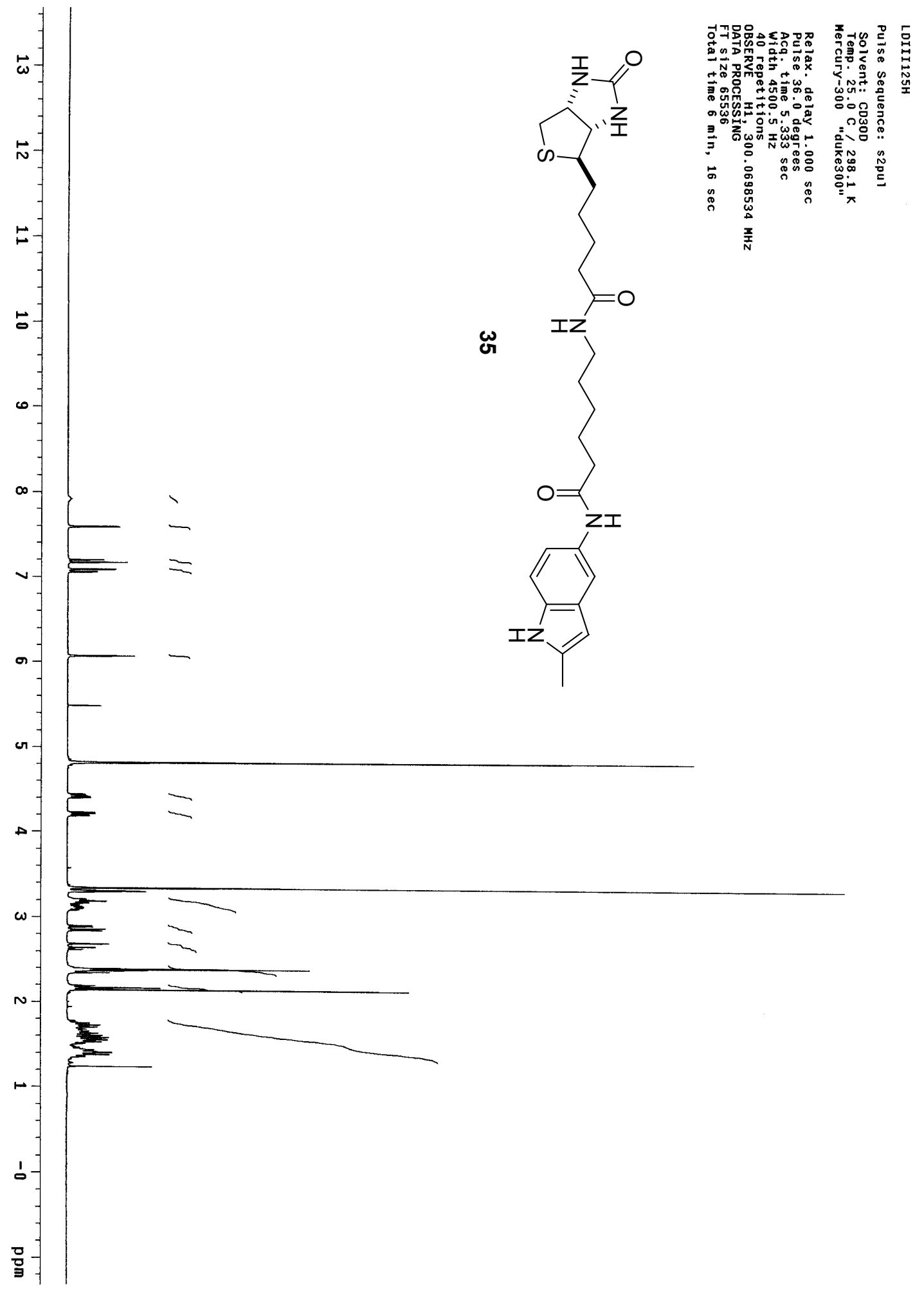




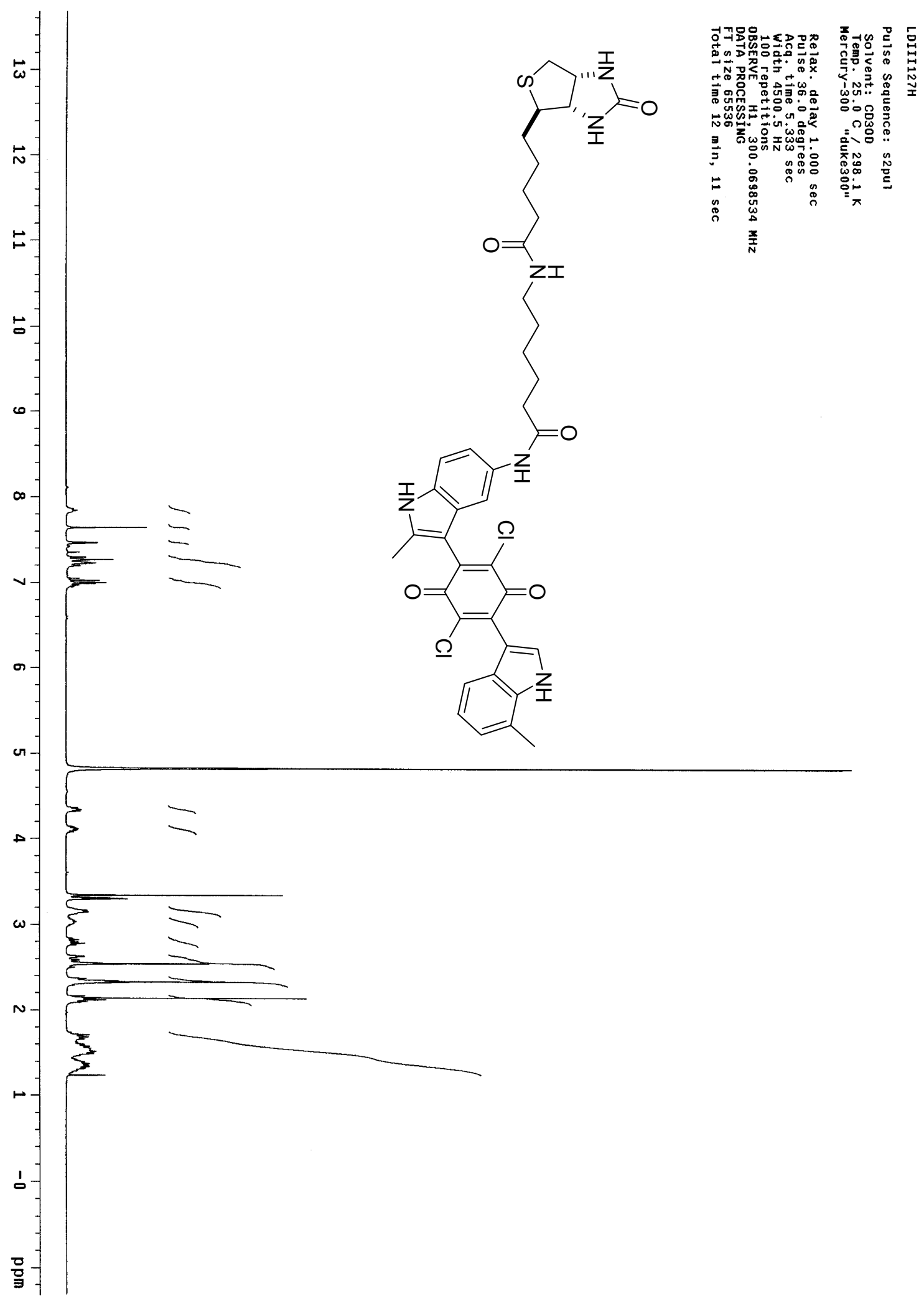




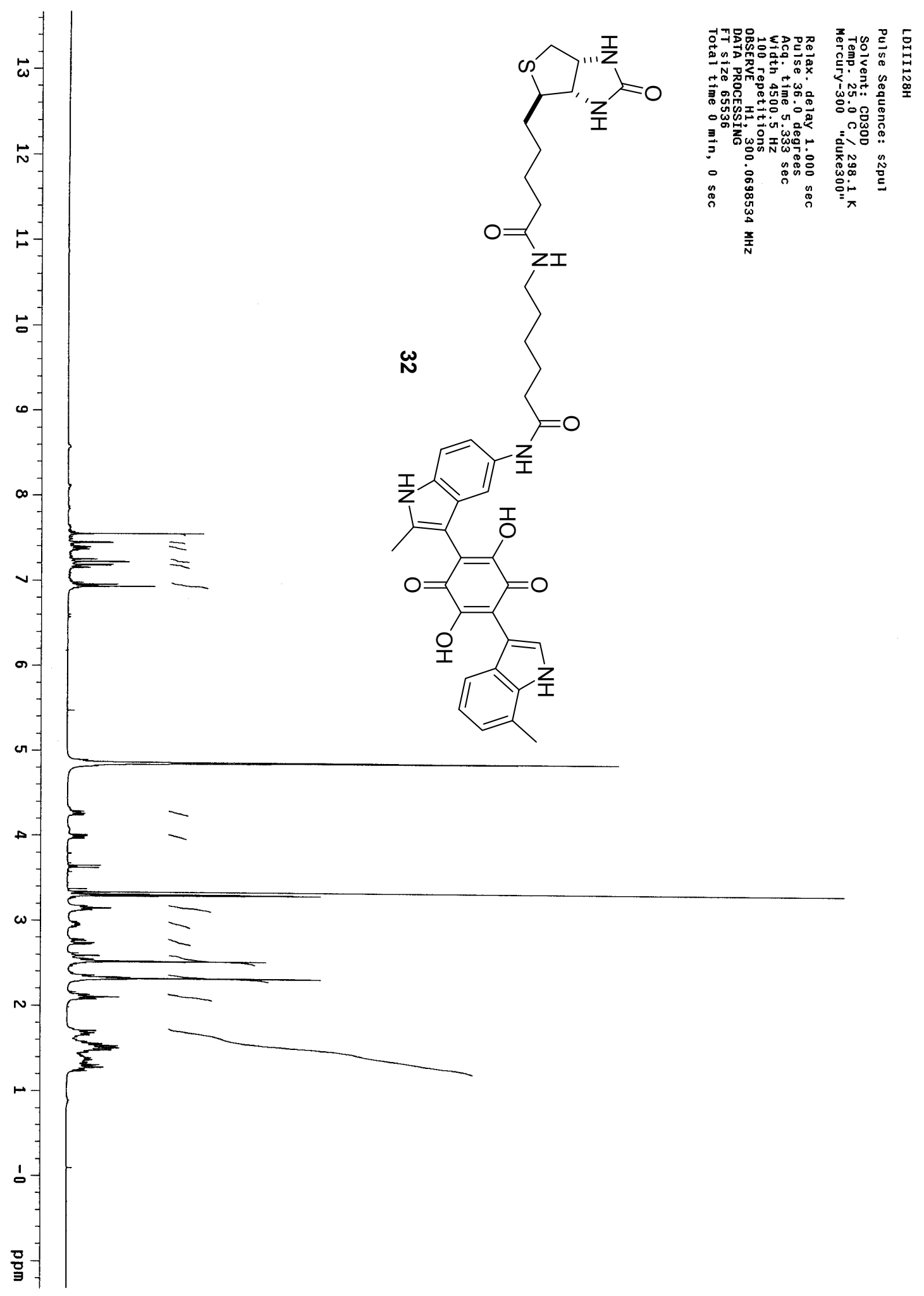




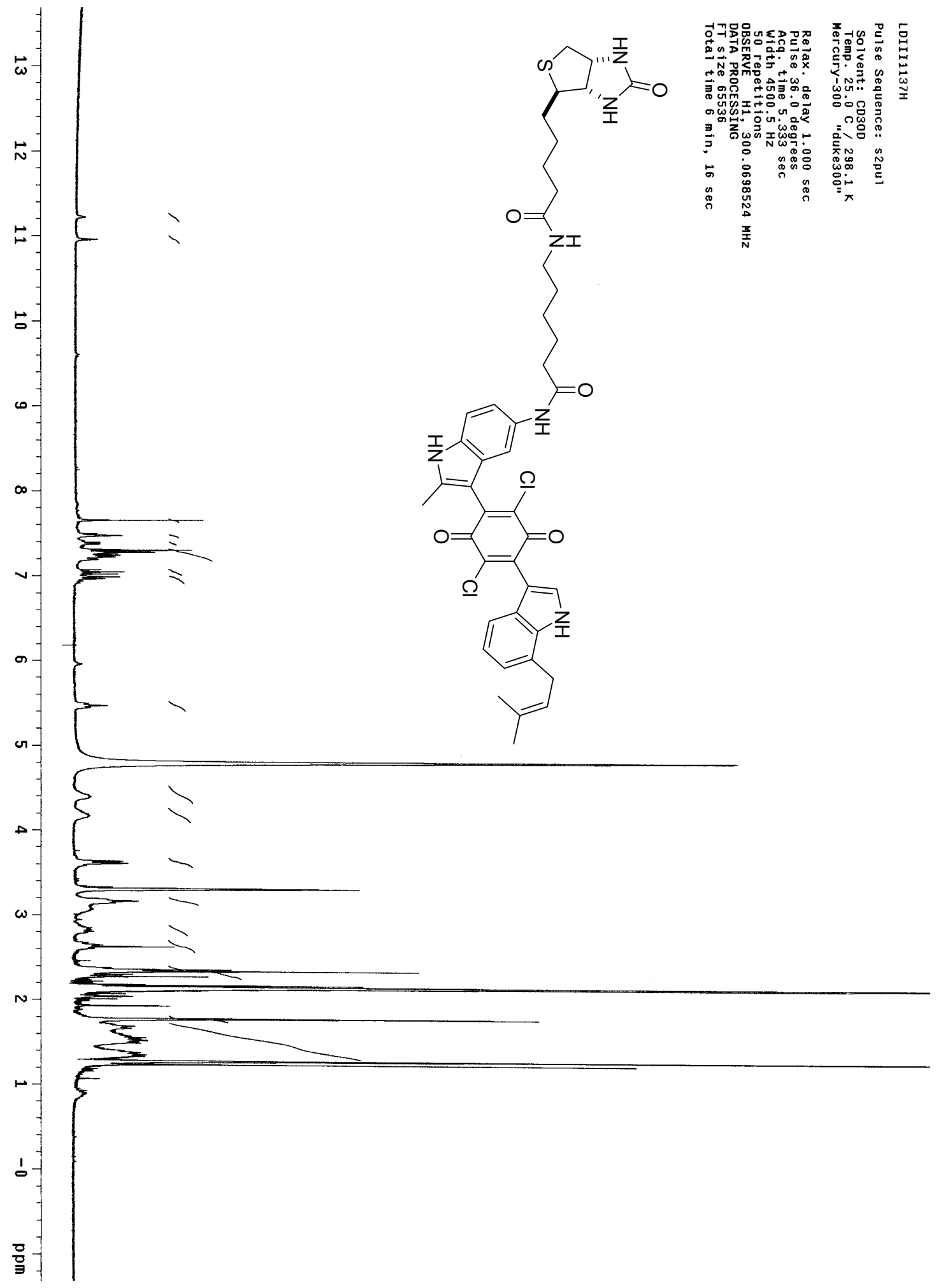

